\title{
POZOSTALOŚCI GÓRNICTWA RUD URANU, TORU I KRUSZCÓW W REJONIE JELENIEJ GÓRY I SZKLARSKIEJ PORĘBY
}

\author{
Robert BORZECKI ${ }^{1}$ \\ Dariusz WÓJCIK ${ }^{2}$ \\ Maciej KALISZ ${ }^{3}$ \\ ${ }^{1}$ Muzeum Minerałów w Nowej Rudzie; minerals@redbor.pl \\ ${ }^{2}$ Czasopismo Odkrywca; dwojcik1966@gmail.com \\ ${ }^{2}$ Badacz niezależny; maciej.kalisz7@gmail.com
}

górnictwo uranu, historia górnictwa, złoże Maciejowa, Trzcińsko, Jagniatków, Wolowa Góra, Budniki, Karpacz, Szklarska Poręba

Artykuł przedstawia zarys historii oraz stan zachowania pozostałości prac górniczych w rejonie Jeleniej Góry. Zaprezentowano w nim wyniki prac inwentaryzacyjnych przeprowadzonych w kopalni „Majewo” w Maciejowej, kopalni skalenia „Przy Starym Domu Celnym” u podnóża zbocza Skalna Brama, kopalniach kruszcó1)w „Hilfe Gottes” i „Friedrich Wilhelm” w Szklarskiej Porębie Górnej, a także w kilku punkach w okolicach Trzcińska, Jagniątkowa, Wołowej Góry, Budnik, Karpacza i Szklarskiej Poręby. Inwentaryzacją objęto 26 obiektów górniczych (szyby, sztolnie, zapadliska powierzchniowe, hałdy pokopalniane itp.), które poddano badaniom mineralogicznym, petrograficznym i radiometrycznym oraz udokumentowano fotograficznie. Prowadzono również badania historyczne w archiwach i bibliotekach.

Podczas prac inwentaryzacyjnych zaobserwowano, że z upływem czasu w opisywanych obiektach górniczych zachodzą zmiany o charakterze destrukcyjnym. Przedstawiono również efekty prowadzonych tu prac rekultywacyjnych, mające na celu zminimalizowanie szkodliwego oddziaływania różnego rodzaju pozostałości prac górniczych na ludzi i środowisko.

$\mathrm{W}$ podsumowaniu podano m.in. szacunkową długość wszystkich wyrobisk górniczych oraz wielkość wydobycia rud uranu (w przeliczeniu na czysty metal) i innych surowców w kopalniach rejonu Jeleniej Góry i Szklarskiej Poręby. 


\section{Wstęp}

Niniejsze opracowanie jest kolejnym z cyklu artykułów omawiających wyniki inwentaryzacji pozostałości prac górniczych prowadzonych $\mathrm{w}$ miejscach występowania rud uranu na obszarze Polski (Borzęcki, 2004; Borzęcki \& Marek, 2016; Borzęcki \& Wójcik, 2017). Inwentaryzację tę rozpoczęto w lecie 1980 r. $\mathrm{W}$ jej trakcie odszukano oraz wielokrotnie przebadano pod kątem mineralogicznym, petrograficznym i historycznym dostępne fragmenty dawnych wyrobisk podziemnych (sztolnie, chodniki, komory poeksploatacyjne) oraz ślady powierzchniowe (odkrywki, zapadliska szybów i sztolni, hałdy pokopalniane). Szczególną uwagę zwrócono na badania tych obiektów pod kątem ewentualnych zagrożeń radiacyjnych. Do pomiarów skażenia powierzchniowego stosowano miernik typu RKP-1-2, a do pomiaru promieniowania emitowanego przez pojedyncze źródła promieniotwórcze radiometr kieszonkowy typu RK-67. Uzyskane wyniki przeliczono zgodnie z jednostkami układu SI. Aby określić stopień zagrożenia radiacyjnego danego obiektu przyjęto, zgodnie $\mathrm{z}$ obowiązującymi przepisami (Rozporzadzenie..., 1153/2002; 1925/2002; 168/2005), że maksymalna, bezpieczna dla człowieka moc równoważnika dawki pochłoniętej promieniowania jonizującego, liczona dla całego ciała, nie powinna przekraczać $20 \mu \mathrm{Sv} / \mathrm{h}$ (= $2000 \mu \mathrm{R} / \mathrm{h}$ ). W przypadku pojedynczych źródeł promieniowania jonizującego za nie stwarzające zagrożenia uznawano fragmenty minerałów lub skał, których aktywność nie przekraczała $1000 \mathrm{~Bq}$.

Podczas prac inwentaryzacyjnych wykonano szczegółową dokumentację fotograficzną badanych obiektów. Możliwe stało się zatem śledzenie destrukcyjnych zmian zachodzących w nich w miarę upływu czasu. Udokumentowano także pozytywne efekty działań podejmowanych przez lokalne władze w celu likwidacji szkód górniczych i rekultywacji hałd pouranowych. Ponadto zwrócono uwagę na nasilające się w ostatnich latach zjawisko penetracji podziemnych wyrobisk górniczych przez nieoficjalne grupy eksploracyjne oraz rozkopywanie hałd pokopalnianych przez różnego rodzaju „poszukiwaczy skarbów".

Równolegle do badań terenowych prowadzono kwerendę dostępnych dokumentów archiwalnych i publikacji, w celu stworzenia możliwie jak najbardziej kompletnej listy obiektów związanych z górnictwem rud uranu, wyjaśnienia przyczyn ich wykonania oraz poznania wyników prowadzonych w nich prac górniczych.

Do prac terenowych wykorzystano nowe narzędzia w postaci numerycznych modeli terenu. Analiza wykonanych w tym systemie map ukształtowania terenu umożliwiła zlokalizowanie kilku nieznanych dotąd obiektów górniczych. 


\section{Budowa geologiczna rejonu Jeleniej Góry}

Rejon Jeleniej Góry położony jest w obrębie bloku karkonosko-izerskiego, którego jądro stanowi intruzja granitu Karkonoszy. Jej wschodnią osłonę tworzy seria skał metamorficznych $\mathrm{w}$ paśmie Rudaw Janowickich (gnejsy, fyllity i amfibolity z soczewkami marmurów dolomitycznych). Na zachodzie intruzja granitu Karkonoszy kontaktuje z serią skał metamorficznych budujących Góry Izerskie (leukogranity, gnejsy i fyllity z wkładkami amfibolitów). Na północy blok karkonosko-izerski oddzielony jest uskokiem śródsudeckim od jednostki kaczawskiej (Borkowska, 1966). Kontakt intruzji granitowej ze skałami metamorficznej osłony jest nierówny, pofalowany. W strefie przykontaktowej w skały te wnika duża ilość apofiz i dajek granitowych oraz różnego rodzaju skał żyłowych (mikrogranity, aplity syenitowe, pegmatyty, lamprofiry i kwarc). Ponadto blok karkonosko-izerski pocięty jest lokalnie licznymi małymi uskokami (Mochnacka, 1967). Najmłodsze z nich miały kierunek NW-SE i były niekiedy wypełnione uranonośną glinką tektoniczną. $Z$ tego powodu budziły one największe zainteresowanie przy poszukiwaniach rud uranu. $\mathrm{Na}$ omawianym obszarze uskoki takie napotkano m. in. w złożu „Majewo” w Maciejowej (część Jeleniej Góry), w punktach „Bobrów” w Trzcińsku, „Jagniątków” i „Wołowa Góra” oraz w okolicach osady Budniki i Wilczej Poręby w Karpaczu (Adamski \& Kaczmarek, 1960).

\section{Punkt poszukiwań rud uranu „Bobrów” w Trzcińsku}

Najstarsza wzmianka mówiąca o występowaniu mineralizacji uranowej w okolicach Trzcińska (niem: Rohrlach, później Rożniewo) pochodzi z 1865 r. Napotkano ją na północno-zachodnim zboczu Góry Tunelowej (440 m n.p.m.), podczas wykonywania prac ziemnych związanych z budową tunelu dla linii kolejowej Wrocław-Jelenia Góra (ryc. 1). Odkrycie to zgłosił pan Chaussy - aptekarz i kolekcjoner minerałów z pobliskiej Miedzianki (Leisner, 1865). Mineralizacja związana była z pokrywającym powierzchnię granitu zwietrzałym skaleniem (glinka kaolinowa w strefie tektonicznej), zawierającym liczne łuskowate skupienia hematytu $\mathrm{Fe}_{2} \mathrm{O}_{3}$ (Leisner, 1865; Lis \& Sylwestrzak, 1986).

W 1949 r., w punkcie zwanym „Bobrów” w Trzcińsku, wykryto 5 anomalii radiometrycznych, które następnie rozpoznano wyrobiskami górniczymi o łącznej długości około $738 \mathrm{~m}$.b. Prace te nie doprowadziły jednak do znalezienia znaczących koncentracji rud uranu, w związku z czym w 1950 r. zostały przerwane. (Adamski \& Kaczmarek, 1960). 
Punkt „Bobrów” w Trzcińsku położony jest na północno-wschodnim zboczu Góry Tunelowej (440 m n.p.m.), w północno-wschodniej części intruzji granitu Karkonoszy. Na obszarze tym zalegają granity biotytowe z licznymi apofizami i dajkami magmowych skał żyłowych (granodioryty, aplity, lamprofiry). Minerały uranu związane tu były z przecinającymi granit szczelinami tektonicznymi o biegu NW-SE. Koncentrowały się one w wypełniającej te szczeliny glince kaolinowej (rozłożony skaleń). Współwystępowały tam ze skupieniami łuskowatego hematytu $\mathrm{Fe}_{2} \mathrm{O}_{3}$, tworząc gniazda o powierzchni do $1 \mathrm{~m}^{2}$. Obecność mineralizacji uranowej stwierdzono tu również w strefie kontaktu granitu biotytowego z dajką lamprofiru (Adamski \& Kaczmarek, 1960; Lis \& Sylwestrzak, 1986).

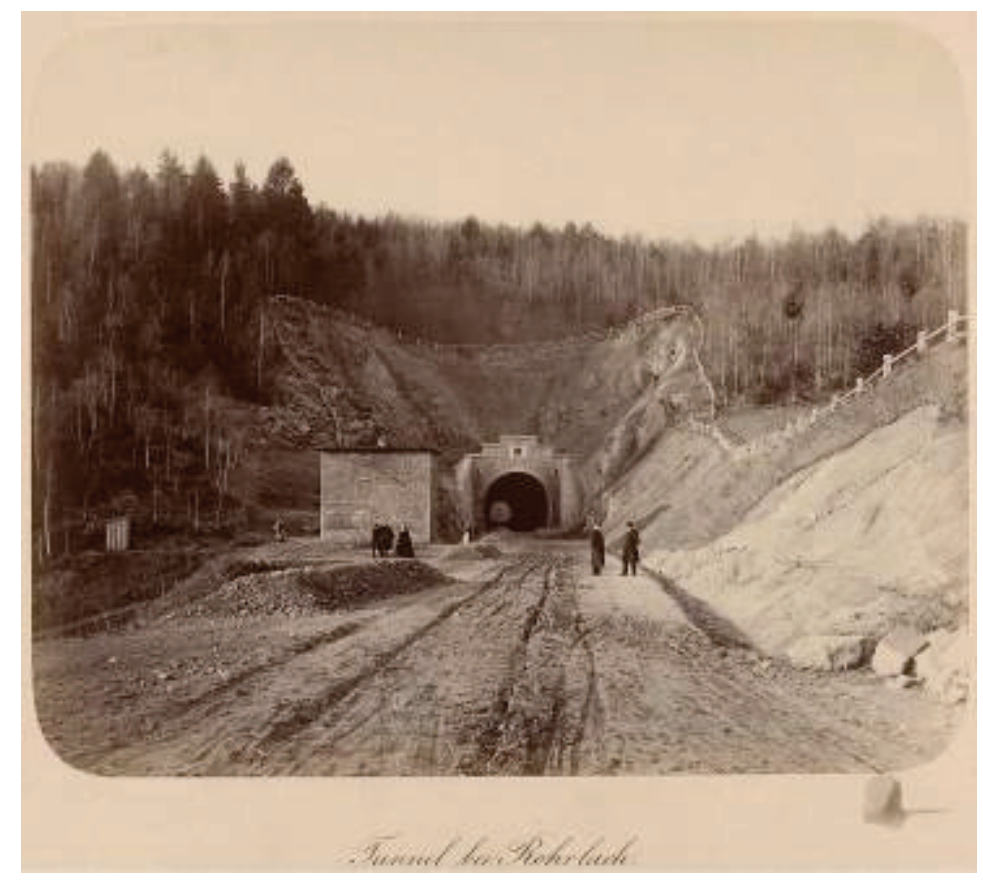

Ryc. 1. Północno-zachodni wylot tunelu kolejowego w Trzcińsku podczas prac budowlanych (dolny-slask.gov.pl)

Fig. 1. North-west opening of the railway tunnel in Trzcińsko during construction works (dolny-slask.gov.pl)

W latach 1949-1950 ze stref zmineralizowanych napotkanych w punkcie „Bobrów” w Trzcińsku wydobyto rudę o zawartości $91 \mathrm{~kg}$ uranu (Adamski \& Kaczmarek, 1960) i obecnie miejsce to uważa się za nieperspektywiczne (Borucki, 1967). Na hałdy zrzucono tam łącznie $4000 \mathrm{~m}^{3}$ urobku skalnego (Sztuk $\mathrm{i}$ in., 1994). Prowadzone w trakcie inwentaryzacji pomiary radiometryczne wykazały, że miejscami zawiera on fragmenty rud uranu. 
Strefy zmineralizowane wykryte w punkcie „Bobrów” w Trzcińsku zostały rozpoznane licznymi szurfami na powierzchni, a także udostępnione wgłębnie szybikami nr 1, 2 i 3 oraz sztolnią nr 1 (ryc. 2). Wykonano je w celu wgłębnego rozpoznania wykrytych na powierzchni anomalii radiometrycznych.

Według przyjętej w artykule numeracji obiekt nr 1 to wybity w 1949 r. szybik nr 1, położony na północno-wschodnim zboczu Góry Tunelowej (440 m n.p.m.), na wysokości około 400 m n.p.m. Napotkano w nim strefę zmineralizowaną, z której wydobyto 0,5 t rudy o zawartości około 0,2\% U (Adamski \& Kaczmarek, 1960).
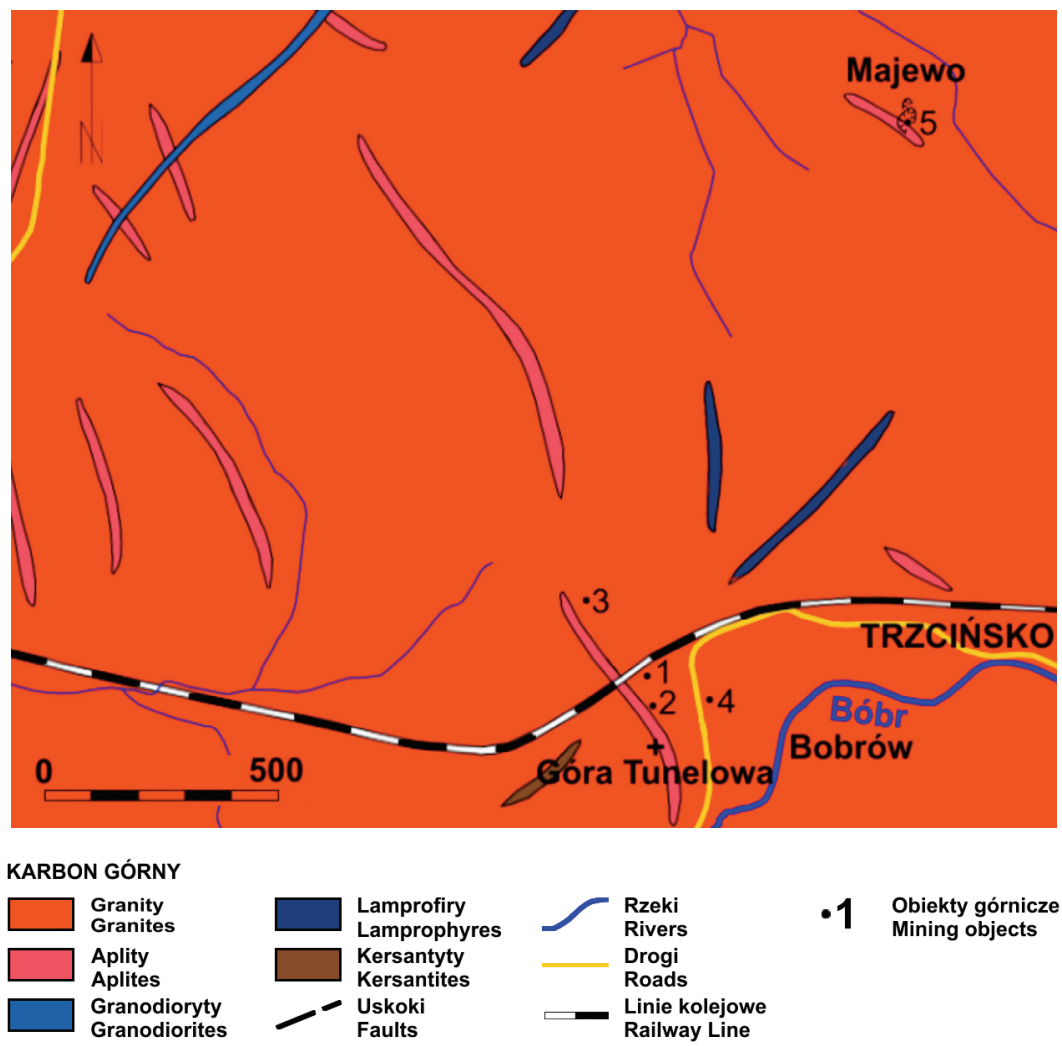

Ryc. 2. Uproszczona mapa geologiczna okolic Trzcińska i Maciejowej

(wg Szałamachy \& Tucholskiej, 1960)

Fig. 2. Geological map of Trzcińsko and Maciejowa area (based on Szałamacha \&Tucholska, 1960)

Obecnie szybik jest niedrożny, gdyż w miejscu jego zrębu powstało zapadlisko (ryc. 3). Poniżej znajduje się hałda. Wśród zalegającego na niej urobku skalnego występują granity. Materiał ten wykazuje na ogół słabą aktywność 
promieniotwórczą, mieszczącą się w przedziale 2-4 Bq. Hałdę porasta drzewostan liściasty i roślinność trawiasta.

Obiekt nr 2 stanowi szybik nr 2 położony na północno-wschodnim zboczu Góry Tunelowej (440 m n.p.m.), na wysokości około 420 m n.p.m. Został on wybity w 1950 r. (Adamski \& Kaczmarek, 1960).

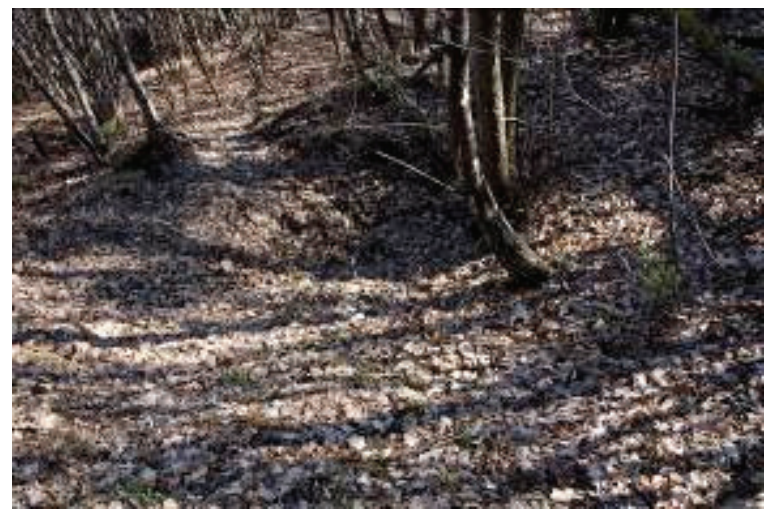

Ryc. 3. Zapadlisko szybiku nr 1 według stanu z 7.04.2018 r. (fot. M. Kalisz)

Fig. 3. Collapsed shaft No. 1 as for 7/04/2018 (photo M. Kalisz)

Obecnie szybik jest niedrożny, gdyż w miejscu jego zrębu powstało zapadlisko (ryc. 4a). Poniżej znajduje się hałda (ryc. 4b). Wśród zalegającego na niej urobku skalnego występują granity. Materiał ten wykazuje na ogół słabą aktywność promieniotwórczą, mieszczącą się w przedziale 2-4 Bq. Hałdę porasta drzewostan liściasty i roślinność trawiasta.
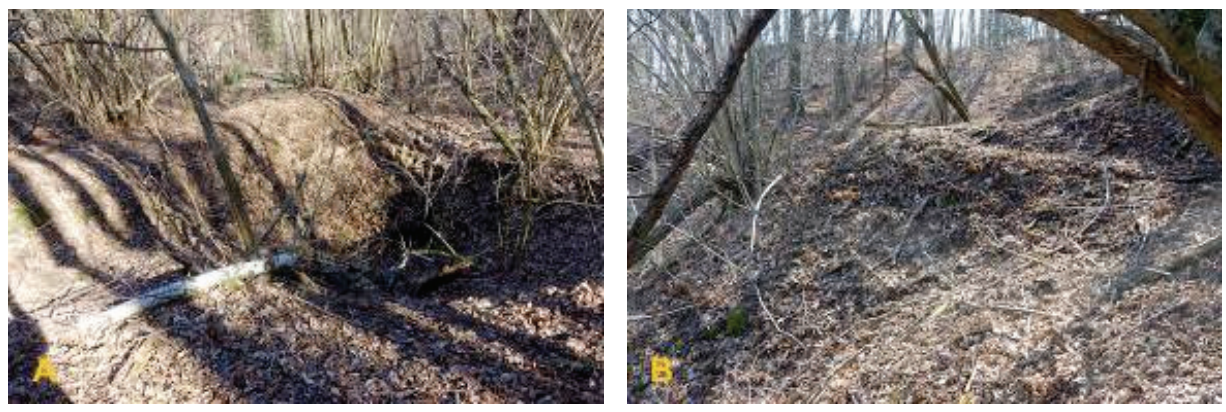

Ryc. 4. Szybik nr 2: A - zapadlisko szybiku, B - hałda (stan z 7.04.2018 r., fot. D. Wójcik) Fig. 4. Shaft No. 2: A - collapsed shaft, B - tailing (photo 07/04/2018, D. Wójcik)

Obiekt nr 3 - wybity w 1949 r. szybik nr 3 - położony jest na północnym zboczu Góry Tunelowej (440 m n.p.m.), na wysokości około 412 m n.p.m. Miał 
on głębokość 14,5 m i udostępniał strefę zmineralizowaną torbernitem, na kontakcie granitu z około 0,5 m miąższości dajką lamprofiru. Strefę tę rozpoznano wcinką. W odległości około $10 \mathrm{~m}$ od szybiku promieniowanie zanikało, w związku z czym prowadzone w nim prace górnicze zostały przerwane (Adamski \& Kaczmarek, 1960).

Obecnie szybik jest niedrożny, gdyż w miejscu jego zrębu powstało zapadlisko (ryc. 5a). Poniżej znajduje się hałda (ryc. 5b). Wśród zalegającego na niej urobku skalnego występują głównie granity, którym w podrzędnych ilościach towarzyszą lamprofiry. Materiał ten wykazuje podwyższoną aktywność promieniotwórczą sięgającą miejscami $20 \mathrm{~Bq}$. Hałdę porasta drzewostan liściasty i roślinność trawiasta.
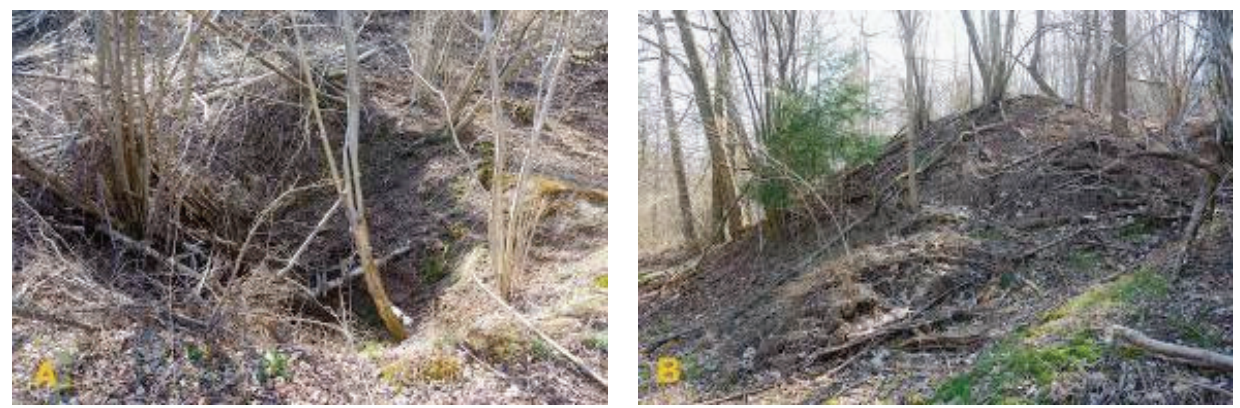

Ryc. 5. Szybik nr 3: A - zapadlisko szybiku, B - hałda (stan z 7.04.2018 r., fot. D. Wójcik) Fig. 5. Shaft No. 3: A - collapsed shaft; B - tailing (photo 07/04/2018, D. Wójcik)

Obiekt nr 4 to sztolnia nr 1 położona u podnóża północno-wschodniego zbocza Góry Tunelowej (440 m n.p.m.), na wysokości około 361 m n.p.m. Została wydrążona w 1950 r., w celu wgłębnego rozpoznania wykrytych na powierzchni anomalii radiometrycznych (poziom -20 m). Miała ona długość $288 \mathrm{~m}$ i była w całości prowadzona w granitach. Na jej poziomie wykonano trzy chodniki o łącznej długości $162 \mathrm{~m}$. Udostępniały one strefę równoległych szczelin o kierunku SW-NE i miąższości do $0,5 \mathrm{~m}$, zawierających gniazda łuskowatego hematytu z mineralizacją uranową. W celu zbadania jednego z takich gniazd, $\mathrm{z}$ chodnika nr 2 wybito prawie pionową dowierzchnię o wysokości około $17 \mathrm{~m}$. W trakcie tych prac wydobyto około 44,608 t rudy o zawartości $91 \mathrm{~kg}$ uranu (Adamski \& Kaczmarek, 1960). Na hałdę zrzucono łącznie około $4000 \mathrm{~m}^{3}$ urobku skalnego (Sztuk i in., 1994).

Obecnie sztolnia jest drożna (ryc. 6a). Wypływa z niej woda która spływa do rzeki Bóbr. Poniżej znajduje się wąska hałda (ryc. 6b). Wśród zalegającego na niej urobku skalnego występują głównie granity, którym w podrzędnych ilościach towarzyszą pegmatyty. Materiał ten wykazuje na ogół słabą aktywność promieniotwórczą, mieszczącą się w przedziale 4-6 Bq. Hałdę porasta drzewostan liściasty i roślinność trawiasta. 

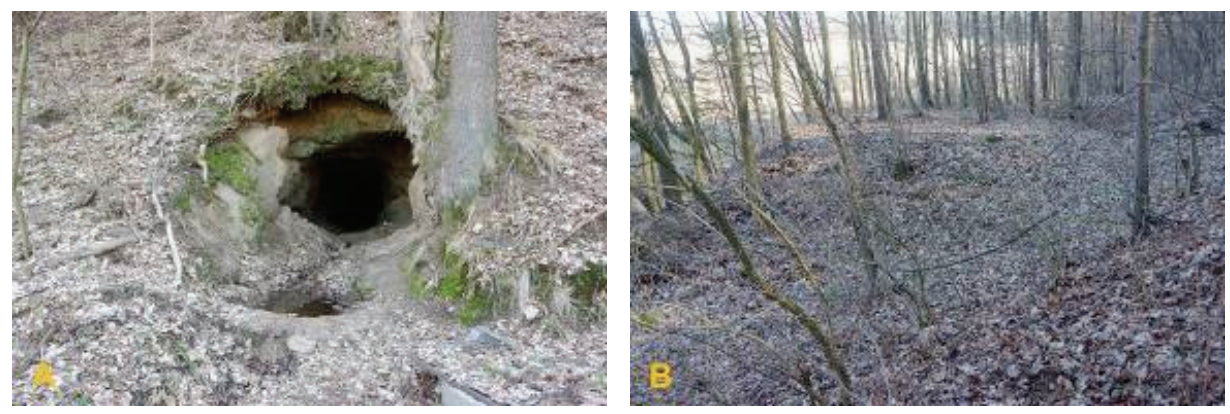

Ryc. 6. Sztolnia nr 1: A - okno, B - hałda (stan z 7.04.2018 r., fot. D. Wójcik)

Fig. 6. Adit No. 1: a - window, b - tailing (photo 07/04/2018, D. Wójcik)

\section{Kopalnia rud uranu „Majewo" w Maciejowej}

Złoże rud uranu „Majewo” w Maciejowej (niem: Maiwaldau) odkryto w 1951 r. Wkrótce potem uruchomiono tu kopalnię o tej samej nazwie. W latach 1955-1956 wykonano w niej 1770 m.b. poziomych i pionowych wyrobisk górniczych. Rozpoznanie złoża prowadzono na dwóch poziomach eksploatacyjnych $(-55 \mathrm{i}-105 \mathrm{~m})$ do głębokości około $105 \mathrm{~m}$ od powierzchni terenu. Pod koniec 1956 r. z powodu zbyt niskich zasobów złoża przerwano prowadzone tu prace górnicze i kopalnię zatopiono (Adamski \& Kaczmarek, 1960).

Złoże „Majewo” położone jest w odległości około $900 \mathrm{~m}$ na południe od wschodniego skraju wsi Maciejowa, w północno-wschodniej części intruzji granitu Karkonoszy. Na obszarze tym zalegają gruboziarniste granity z licznymi żyłami lamprofirów przecięte czterema strefami tektonicznymi o biegu NE-SW. Mineralizacja uranowa związana była $\mathrm{z}$ trzema $\mathrm{z}$ tych stref:

- strefą nr 1 (najzasobniejszą) o miąższości 0,2-3 m, przebiegającą w odległości około $157 \mathrm{~m}$ na północny wschód od zrębu szybu $\mathrm{nr} 1$,

- strefą $\mathrm{nr} 2$ o miąższości $0,3-0,6 \mathrm{~m}$, przebiegającą w odległości około $100 \mathrm{~m}$ na północ od zrębu szybu $\mathrm{nr} 1$,

- strefą nr 4 o miąższości $0,5-0,7 \mathrm{~m}$, przebiegającą w odległości około $210 \mathrm{~m}$ na południowy wschód od szybu $\mathrm{nr} 1$.

$\mathrm{W}$ strefach tych minerały uranu (uraninit $\mathrm{UO}_{2}$ ) tworzyły gniazda w wypełniających je glinkach tektonicznych i brekcjach skalnych.

Strefa nr 3 o miąższości do $10 \mathrm{~m}$, przebiegająca w odległości około $90 \mathrm{~m}$ na południowy wschód od szybu nr. 1 była całkowicie płonna (Adamski \& Kaczmarek, 1960; Lis \& Sylwestrzak, 1986).

W 1955 r. na podstawie prób pobranych na poziomie $-55 \mathrm{~m}$, całkowite zasoby złoża szacowano wstępnie na $5650 \mathrm{~kg}$ uranu. W 1956 r. po uwzględnieniu 
wyników badań uzyskanych z poziomu -105 m, zmniejszono je do $955 \mathrm{~kg}$ uranu. W tej sytuacji złoże uznano za nieperspektywiczne i nie podjęto próby jego eksploatacji. W latach 1955-1956 na przykopalnianą hałdę zrzucono łącznie $9400 \mathrm{~m}^{3}$ urobku skalnego (Adamski \& Gawor, 1994). W późniejszym okresie został on prawie całkowicie wybrany. Prowadzone w trakcie inwentaryzacji pomiary radiometryczne wykazały, że materiał z hałdy nie zawiera fragmentów rud uranu.

Złoże „Majewo” zostało rozpoznane szurfami na powierzchni, a także udostępnione wgłębnie szybem nr 1 (ryc. 1).

Obiekt nr 5 - szyb nr 1 - położony jest w odległości około 900 metrów na południe od wschodniego skraju wsi Maciejowa, na wysokości około $370 \mathrm{~m}$ n.p.m. Został wybity w latach 1955-1956 w celu wgłębnego rozpoznania wykrytych badaniami powierzchniowymi stref $\mathrm{z}$ mineralizacją uranową. Miał on głębokość około $110 \mathrm{~m}$ i udostępniał dwa poziomy eksploatacyjne (-55 i $-105 \mathrm{~m}$ ). Ogółem wykonano w nim $1660 \mathrm{~m} . \mathrm{b}$. poziomych wyrobisk górniczych. Efektem tych prac było wykrycie trzech stref rudonośnych, ale ze względu na zbyt małe zasoby uranu nie podjęto ich eksploatacji (Adamski \& Kaczmarek, 1960)

Obecnie szyb jest niedrożny, gdyż w miejscu jego zrębu powstało głębokie zapadlisko (ryc. 7a). Obok widoczne są betonowe podpory wieży szybowej i fundamenty maszyny wyciągowej. Wokół szybu znajdują się pozostałości rozległej hałdy (ryc. 7b). W'́ród zalegającego na niej urobku skalnego przeważają granity którym w podrzędnych ilościach towarzyszą lamprofiry i minerały żyłowe (kwarc $\left.\mathrm{SiO}_{2}\right)$. Materiał ten wykazuje na ogół słabą aktywność promieniotwórczą, mieszczącą się $\mathrm{w}$ przedziale 4-8 Bq. Hałdę porasta drzewostan liściasty i roślinność trawiasta.
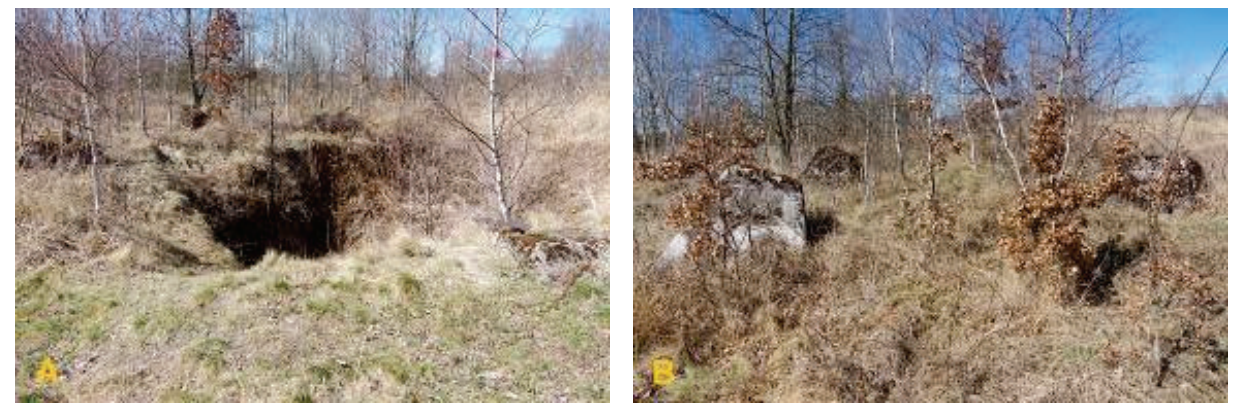

Ryc. 7. Szyb (złoże „Majewo”): A - zapadlisko szybu, B - betonowe podpory wieży szybowej i pozostałości hałdy ( $\operatorname{stan}$ z 7.04.2011 r., fot. D. Wójcik)

Fig. 7. Adit ("Majewo" deposit): A - collapsed shaft, B - concrete supports of the shaft tower and tailing remains (photo 07/04/2018, D. Wójcik) 


\section{Punkt poszukiwań rud uranu „Jagniątków”}

W 1954 r. w Jagniątkowie (niem. Agnetendorf, później Agnieszków) wykryto anomalię radiometryczną, którą następnie rozpoznano wyrobiskami górniczymi o łącznej długości $310 \mathrm{~m}$. Prace te nie doprowadziły jednak do znalezienia znaczących koncentracji rud uranu, w związku z czym zostały przerwane (Adamski \& Kaczmarek, 1960).

Punkt „Jagniątków” położony jest na południowo-wschodnim zboczu Góry Sośnik (650,2 m n.p.m.), w południowej części metamorficznej osłony intruzji granitu Karkonoszy. Na obszarze tym zalegają granity biotytowe z dajkami i apofizami żyłowych skał magmowych (aplity, granity alkaliczne). Mineralizacja uranowa związana tu była z przecinającymi granit szczelinami tektonicznymi o biegu NW-SE. Miały one szerokość do $2 \mathrm{~m}$ i były wypełnione glinkami oraz brekcjami tektonicznymi. Zawartość uranu malała wraz z głębokością, dlatego przyjęto infiltracyjne pochodzenie tej mineralizacji (Adamski \& Kaczmarek, 1960). Zaobserwowany przez autorów znaczny udział nontronitu w glinkach wypełniających szczeliny tektoniczne może wskazywać, że w jej tworzeniu pewną rolę odegrały także roztwory hydrotermalne.

Po stwierdzeniu ubożenia mineralizacji uranowej ze wzrostem głębokości, wykryte tu strefy zmineralizowane uznano za nieperspektywiczne (Adamski \& Kaczmarek, 1960) i nie podjęto próby ich eksploatacji (Borucki, 1967). Na hałdę zrzucono łącznie $1600 \mathrm{~m}^{3}$ urobku skalnego (Sztuk i in., 1994). Prowadzone $\mathrm{w}$ trakcie inwentaryzacji pomiary radiometryczne wykazały, że nie zawiera on fragmentów rud uranu.

Strefa zmineralizowana wykryta w punkcie „Jagniątków” została rozpoznana licznymi szurfami na powierzchni, a także udostępniona wgłębnie Sztolnią nr 1 (ryc. 8).

Obiekt $\mathrm{nr}$ 6, czyli Sztolnia $\mathrm{nr} 1$ położona jest u podnóża południowo-wschodniego zbocza Góry Sośnik (650,2 m n.p.m.), na wysokości około 580 m n.p.m., przy ulicy Saneczkowej w Jagniątkowie. Została wydrążona w 1955 r., w celu wgłębnego rozpoznania wykrytej na powierzchni anomalii radiometrycznej (poziom $-55 \mathrm{~m}$ ). Miała ona długość około $260 \mathrm{~m}$ i była w całości prowadzona w granitach. Na jej poziomie wykonano łącznie około $310 \mathrm{~m} . b$. poziomych wyrobisk górniczych (Adamski \& Kaczmarek, 1960). Efektem tych prac było wykrycie tylko jednej strefy z bardzo ubogą mineralizacją uranową, w związku z czym zostały one przerwane. W $1994 \mathrm{r}$ sztolnia była niedrożna (Sztuk, 1994), ale przed 2007 r. została otwarta. Dokonano wówczas jej pomiaróa)w i sporządzono szczegółowy profil geologiczny (Zagożdżon \& Zagożdzon, 2007).

Obecnie sztolnia jest drożna, ale jej okno przegradza około $2 \mathrm{~m}$ wysokości obwał (ryc. 9a), za którym gromadzi się woda. Poniżej po drugiej stronie ulicy 
Saneczkowej znajduje się hałda (ryc. 9b). Wśród zalegającego na niej urobku skalnego występują głównie granity, którym w podrzędnych ilościach towarzyszą fragmenty żył aplitowych. Materiał ten wykazuje na ogół słabą aktywność promieniotwórczą, mieszczącą się $\mathrm{w}$ przedziale 2-4 Bq. Hałdę porasta drzewostan liściasty i roślinność trawiasta.

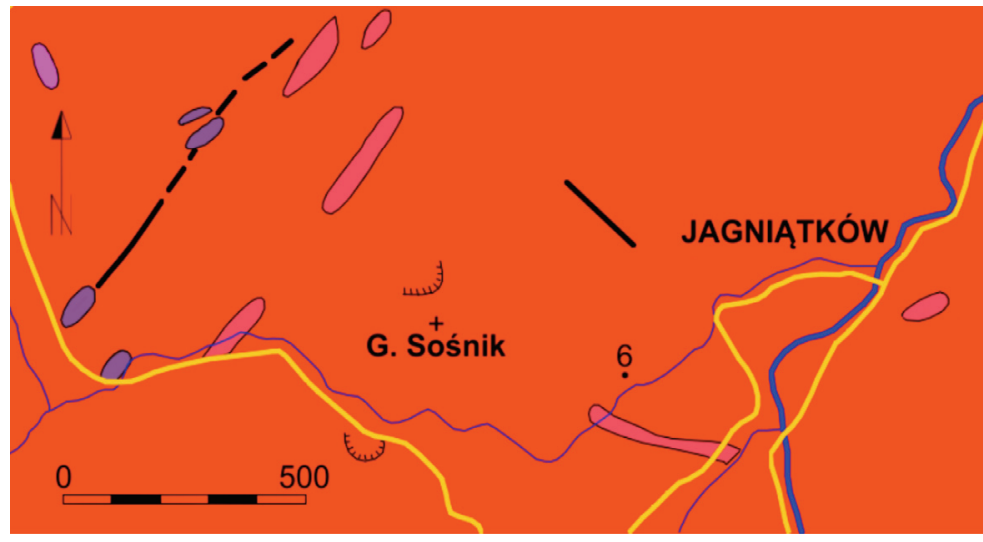

KARBON GÓRNY

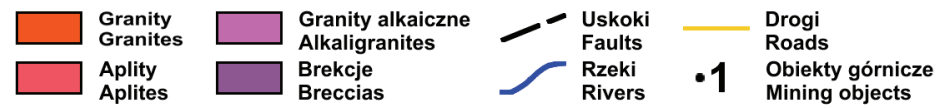

Ryc. 8. Uproszczona mapa geologiczna okolic Jagniątkowa

(wg Mierzejewski, 1982)

Fig. 8. Geological map of Jagniątków area (based on Mierzejewski, 1982)
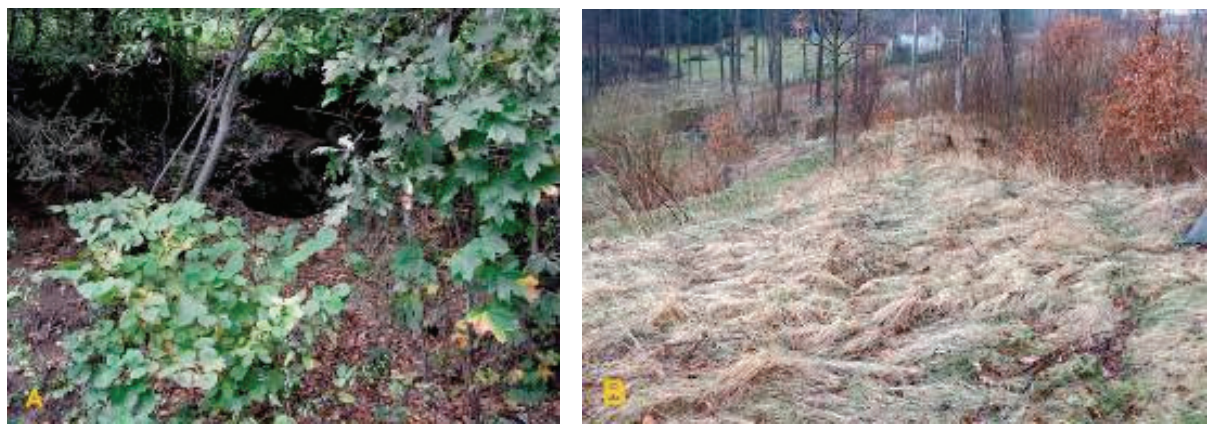

Ryc. 9. Sztolnia nr 1: A - okno według stanu z 1.10.2010 r. (fot. R. Borzęcki), B - hałda według stanu z 8.04.2018 r. (fot. D. Wójcik)

Fig. 9. Adit No 1: A - window as for 01/10/2010 (photo R. Borzęcki), $\mathrm{B}$ - tailing as for $08 / 04 / 2018$ (photo D. Wójcik) 


\section{Punkt poszukiwań rud uranu „Wołowa Góra”}

W 1954 r. w punkcie zwanym „Wołowa Góra” w Karkonoszach wykryto anomalie radiometryczne, które następnie rozpoznano powierzchniowo. W $1957 \mathrm{r}$. wznowiono poszukiwania wykonując tu łącznie 99 m.b. pionowych i poziomych wyrobisk górniczych. Prace te nie doprowadziły jednak do znalezienia znaczących koncentracji rud uranu, w związku z czym zostały przerwane (Adamski \& Kaczmarek, 1960).

Punkt ten położony jest na przełęczy pomiędzy Górą Czoło (1266 m n.p.m.) i Wołową Górą (1032 m n.p.m.), w południowej części metamorficznej osłony granitu Karkonoszy. Na obszarze tym zalegają różne odmiany granitognejsów z wkładkami fyllitów.

Mineralizacja uranowo-torowa (branneryt) związana tu była ze szczeliną tektoniczną o biegu NW-SE, przecinającą granitognejsy turmalinowe, w odległości $1300 \mathrm{~m}$ od ich kontaktu z intruzją granitu Karkonoszy. Występowała ona $\mathrm{w}$ postaci rozproszonej $\mathrm{w}$ wypełniającej tę szczelinę żyle kwarcowo-turmalinowej (Lis i in., 1965).

W 1957 r. ze strefy zmineralizowanej napotkanej w punkcie „Wołowa Góra” wydobyto około 2,5 tony rudy (Adamski \& Kaczmarek, 1960) o zawartości $5,025 \mathrm{~kg}$ uranu i obecnie miejsce to uważa się za nieperspektywiczne (Borucki, 1967). Na hałdy zrzucono tam łącznie $450 \mathrm{~m}^{3}$ urobku skalnego (Sztuk i in., 1994). Prowadzone w trakcie inwentaryzacji pomiary radiometryczne wykazały, że miejscami zawiera on fragmenty rud uranu.

Strefa zmineralizowana wykryta w punkcie „Wołowa Góra” została rozpoznana szurfami na powierzchni, a także udostępniona wgłębnie szybikami nr 1 i 2 (ryc. 10), rozpoznającymi ją wgłębnie.

Obiekt nr 7, czyli szybik nr 1 został wybity w $1957 \mathrm{r}$. Jest położony na południowym zboczu Wołowej Góry (1032 m n.p.m.) na wysokości około $1015 \mathrm{~m}$ n.p.m. Był on szybikiem poszukiwawczym o głębokości 7,5 m. Ogółem wykonano w nim około 45 m.b. poziomych wyrobisk górniczych oraz jeden ślepy szybik o głębokości 1,5 m (Adamski \& Kaczmarek, 1960). W 1986 r. szybik był już niedrożny, obecnie w miejscu jego zrębu powstało głębokie zapadlisko (ryc. 11a).

Obiekt nr 8 to szybik nr 2, położony na południowym zboczu Wołowej Góry (1032 metry n.p.m.) na wysokości około 1015 m n.p.m. Został wybity w 1957 r. Był on szybikiem rozpoznawczym o głębokości 14,5 m. Ogółem wykonano w nim około 32 m.b. poziomych wyrobisk górniczych (Adamski \& Kaczmarek, 1960). W 1986 roku szybik ten miał jeszcze w pełni zachowaną drewnianą obudowę, ale był całkowicie zatopiony. Obecnie jest niedrożny, gdyż w miejscu jego zrębu powstało zapadlisko (ryc. 11b), które jest prawie całkowicie wypełnione wodą. $\mathrm{Na}$ jego ścianach zachowały się pozostałości oryginalnej obudowy drewnianej. 


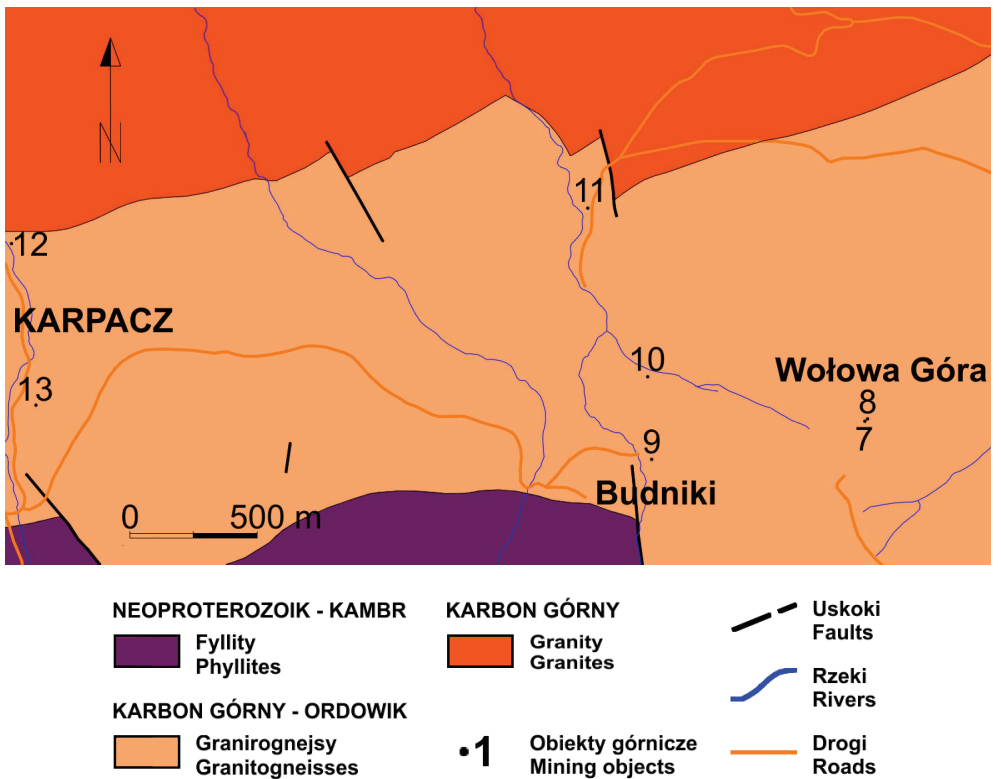

Ryc. 10. Uproszczona mapa geologiczna rejonu Karpacza i Budnik (wg Szałamachy, 1960 oraz Kozdroja i in., 2009)

Fig 10. Geological map of Karpacz and Budniki area (based on Szałamacha, 1960 and Kozdrój et al., 2009)
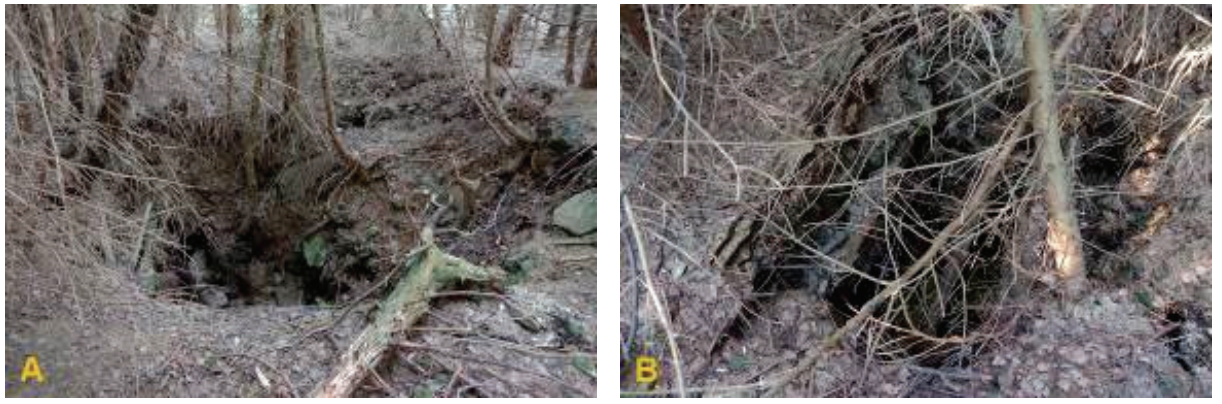

Ryc. 11. Wyrobiska „Wołowej Góry”: A - zapadlisko szybiku nr 1, B - zrąb szybiku nr 2 (stan z 1.04.2017 r., fot. D. Wójcik)

Fig. 11. Excavations of "Wołowa Góra": A - collapsed shaft No. 1, B - Shaft No. 2 portal (photo 01/04/2017, D. Wójcik)

Obok zapadlisk obu szybików znajduje się hałda (ryc. 12). Wśród zalegającego na niej urobku skalnego występują głównie granitognejsy turmalinowe, którym w podrzędnych ilościach towarzyszą minerały żyłowe (kwarc). Materiał ten wykazuje podwyższoną aktywność promieniotwórczą sięgającą miejscami $200 \mathrm{~Bq}$. Hałdę porasta drzewostan iglasty. 
W lesie w okolicy szybików znajdują się pozostałości kilku długich szurfów poszukiwawczych.

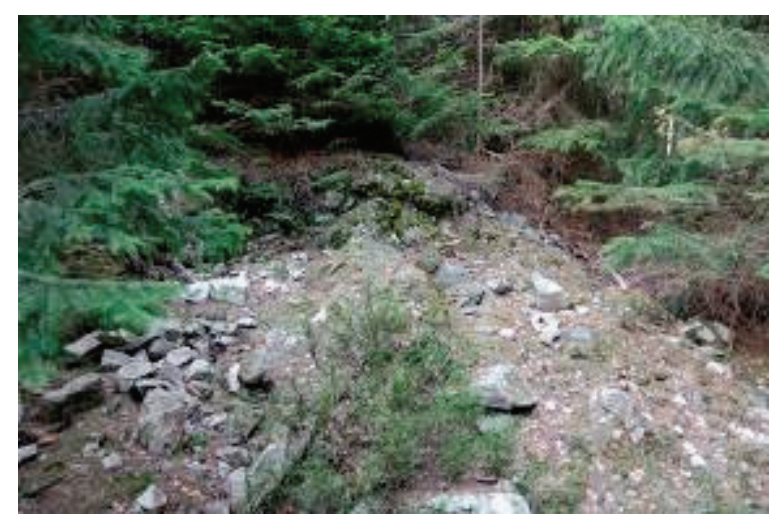

Ryc. 12. Hałda szybików nr 1 i 2 według stanu z 1.04.2017 r. (fot. D. Wójcik)

Fig. 12. Tailing of Shafts No. 1 i No 2 as for 01/04/2017 (photo D. Wójcik)

\section{Punkt poszukiwań rud uranu „Budniki”}

W 1952 r., w okolicach dawnej osady Budniki (niem. Forstbaude), na przestrzeni około $600 \mathrm{~m}$ wykryto kilkanaście punktów z mineralizacją uranową (Adamski \& Kaczmarek, 1960). W latach 1952-1954 wydrążono tu około 1822 m.b. poziomych wyrobisk górniczych (Sztuk i in., 1994). Prace te nie doprowadziły jednak do znalezienia znaczących koncentracji rud uranu, w związku z czym zostały przerwane (Adamski \& Kaczmarek, 1960).

Punkt „Budniki” położony jest na zachodnim zboczu Wołowej Góry (1040,8 m n.p.m.), w południowej części metamorficznej osłony intruzji granitu Karkonoszy. Na obszarze tym zalegają różne odmiany granitognejsów z wkładkami fyllitów. Mineralizacja uranowa miała tu różnorodny charakter, zarówno pod względem składu mineralnego jak i formy występowania.

W latach 1952-1954 ze stref zmineralizowanych napotkanych w punkcie „Budniki” wydobyto rudę o zawartości $30 \mathrm{~kg}$ uranu (Adamski \& Kaczmarek, 1960) i obecnie miejsce to uważa się za nieperspektywiczne (Borucki, 1967). $\mathrm{Na}$ hałdy zrzucono tam łącznie około $8900 \mathrm{~m}^{3}$ (25000 t) urobku skalnego (Sztuk i in., 1994; Sroga, 1997). Prowadzone w trakcie inwentaryzacji pomiary radiometryczne wykazały, że miejscami zawiera on fragmenty rud uranu.

Trzy najbardziej obiecujące strefy mineralizowane wykryte w punkcie Budniki zostały rozpoznane szurfami na powierzchni, a także udostępnione sztolniami nr 21, 22 i 23 (ryc. 10), w których przeprowadzono wgłębne rozpoznanie. 
Obiekt nr 9 to sztolnia nr 21 położona w dolinie potoku Malina, na wysokości 850,00 m n.p.m., w miejscu, w którym niegdyś znajdowała się osada Budniki (Sztuk i in., 1994). Jej drążenie rozpoczęto w 1952 r., była sztolnią poszukiwawczą (Adamski \& Kaczmarek, 1960). Miała ona długość 275 m, na jej poziomie wykonano łącznie 600 m.b. wyrobisk górniczych. Efektem tych prac było wykrycie kilku gniazd z mineralizacją uranową tkwiących w szczelinie tektonicznej o kierunku NE-SW, w miejscu gdzie przecinała ona wkładkę fyllitów w granitognejsach (chodnik nr 2) oraz niewielkiej strefy zmineralizowanej, występującej w spękaniach granitognejsów (Adamski \& Kaczmarek, 1960). W 1953 r. z powodu braku perspektyw na znalezienie znaczących koncentracji rud uranu, prace te zostały przerwane. Na hałdę zrzucono tam łącznie około $2700 \mathrm{~m}^{3}$ urobku (Adamski, 1986). W 1986 r. został on jednak w znacznej części wybrany i wykorzystany do utwardzenia drogi wiodącej z polany Budniki w kierunku Karpacza.

Obecnie sztolnia jest drożna, ale jej okno przegradza około 1,5 m wysokości obwał (ryc. 13a). Przepływa nad nim woda, która spływa bezpośrednio do potoku Malina i dalej do rzeki Jedlica. Poniżej sztolni, tuż przy potoku, znajdują się pozostałości hałdy (ryc. 13b). Wśród zalegającego na niej urobku skalnego występują głównie granitognejsy, którym w podrzędnych ilościach towarzyszą fyllity i kataklazyty. Materiał ten wykazuje podwyższoną aktywność promieniotwórczą sięgającą miejscami $240 \mathrm{~Bq}$. Hałdę porasta drzewostan iglasty.
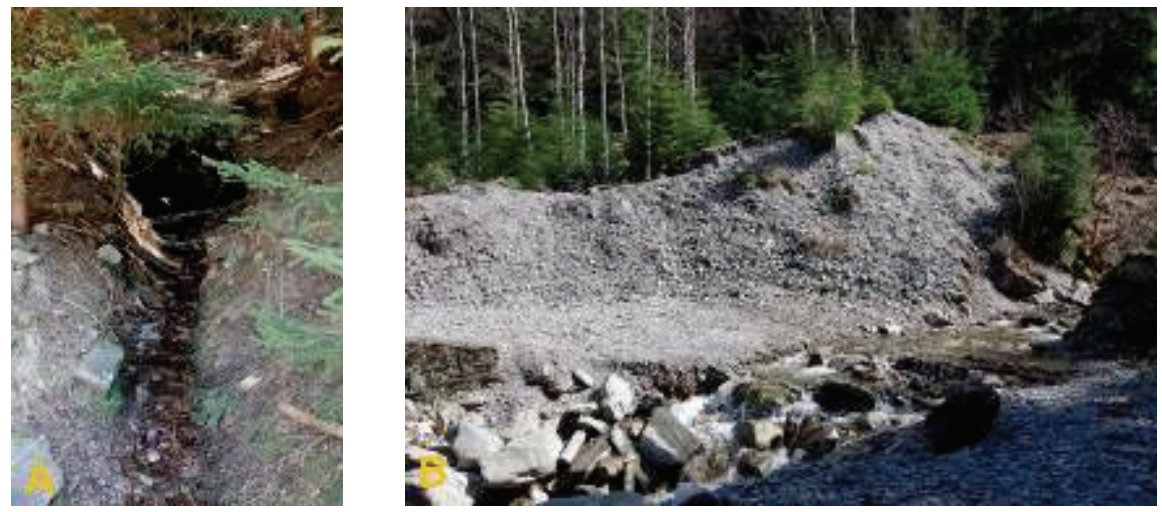

Ryc. 13. Sztolnia nr 21: A - okno, B - pozostałości hałdy (stan z 1.04.2017 r., fot. D. Wójcik)

Fig. 13. Adit No. 21: A - window, B - tailing remains (photo 01/04/2017, D. Wójcik)

Obiekt nr 10 - sztolnia nr 22 - położona jest w dolinie bezimiennego potoku, na zachodnim zboczu Wołowej Góry (1040,8 m n.p.m.), na wysokości około 802 m n.p.m. Jej drążenie rozpoczęto w 1952 r., miała ona długość 162 m (Adamski, 1986). Na jej poziomie wykonano łącznie około 350 m.b. wyrobisk 
górniczych. Efektem tych prac było wykrycie kilku soczewek lamprofirów $\mathrm{z}$ rozproszoną mineralizacją uranowo-torową (uranothoryt). W $1953 \mathrm{r}$. z powodu braku perspektyw na znalezienie znaczących koncentracji rud uranu, prace te zostały przerwane, a początkowy odcinek sztolni rozstrzelony (Adamski \& Kaczmarek, 1960). Na hałdę zrzucono tam łącznie około $1700 \mathrm{~m}^{3}$ urobku skalnego (Adamski, 1986).

Obecnie sztolnia jest niedrożna, gdyż na jej początkowym odcinku powstało podłużne zapadlisko (ryc. 14a). Poniżej, tuż przy potoku znajduje się wąska hałda (ryc. 14b). Wśród zalegającego na niej urobku skalnego występują głównie granitognejsy, którym w podrzędnych ilościach towarzyszą fyllity. Materiał ten wykazuje na ogół słabą aktywność promieniotwórczą, mieszczącą się w przedziale $2-8 \mathrm{~Bq}$. Hałdę porasta drzewostan iglasty.
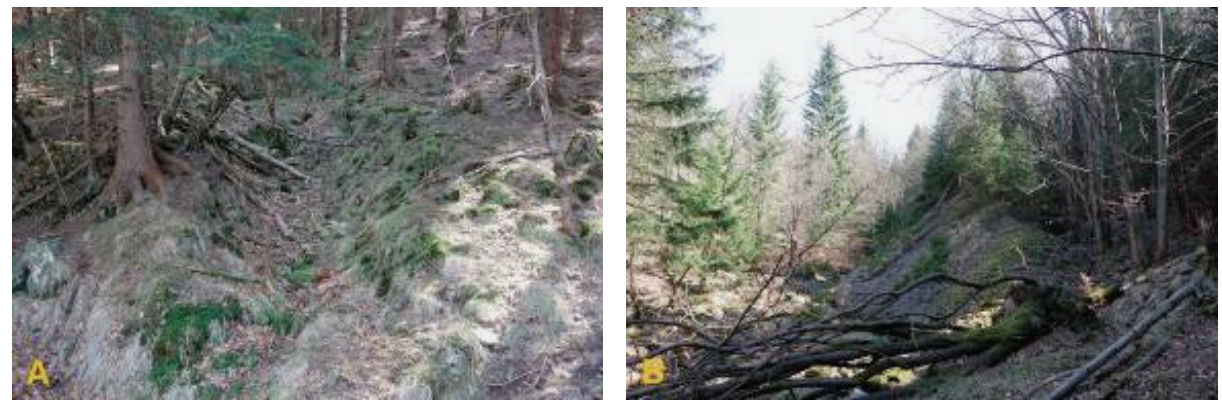

Ryc. 14. Sztolnia nr 22: A - roznos, B - hałda ( $\operatorname{stan}$ z 1.04.2017 r., fot. D. Wójcik)

Fig. 14. Adit No. 22: A - remains, B - tailing (photo 01/04/2017, D. Wójcik)

Obiekt nr 11, czyli sztolnia nr 23, położony jest w dolinie potoku Malina, na zachodnim zboczu Wołowej Góry, na wysokości około 695 m n.p.m. Została wydrążona w 1954 r. i osiągnęła długość około $210 \mathrm{~m}$. Na jej poziomie wykonano łącznie około 750 m.b. wyrobisk górniczych. Efektem tych prac było wykrycie tylko drobnych przejawów wtórnej mineralizacji uranowej, w związku z czym w 1955 r. zostały one wstrzymane. Na hałdę zrzucono tam łącznie około $3800 \mathrm{~m}^{3}$ urobku skalnego (Adamski, 1986).

Obecnie sztolnia jest niedrożna, gdyż w miejscu jej okna powstało zapadlisko (ryc. 15a). Wypływa spod niego woda, która spływa bezpośrednio do potoku Malina i dalej do rzeki Jedlica. Poniżej, tuż przy potoku znajduje się wąska hałda (ryc. 15b). Wśród zalegającego na niej urobku skalnego występują głównie granitognejsy, którym w podrzędnych ilościach towarzyszą fyllity i minerały żyłowe (kwarc). Materiał ten wykazuje na ogół słabą aktywność promieniotwórczą, mieszczącą się w przedziale 2-4 Bq. Hałdę porasta drzewostan iglasty i roślinność trawiasta. 

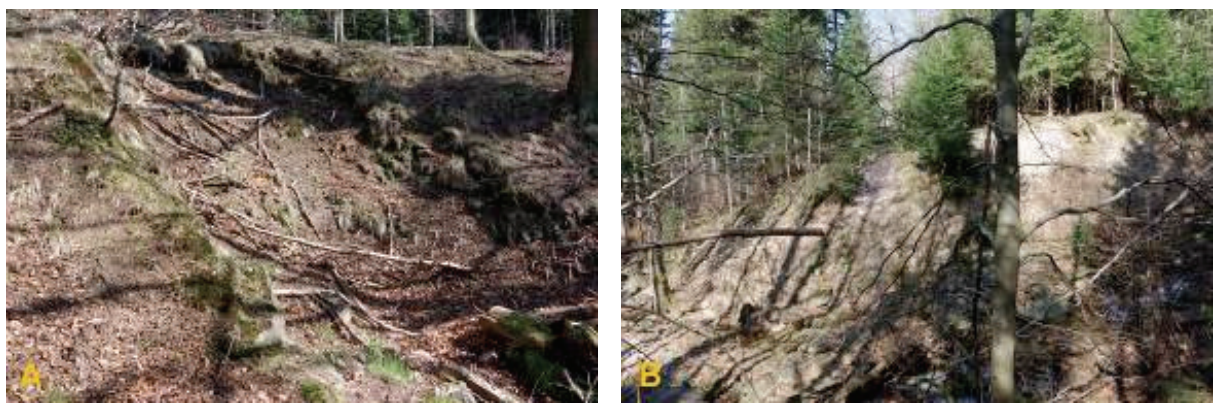

Ryc. 15. Sztolnia nr 23: A - zapadnięte okno, B - hałda (stan z 1.04.2017 r., fot. D. Wójcik)

Fig. 15. Adit No. 23: A - collapsed portal, B - tailing (photo 01/04/2017, D. Wójcik)

\section{Okolice Wilczej Poręby w Karpaczu}

Najstarsza wzmianka mówiąca o występowaniu mineralizacji uranowej w Wilczej Porębie (niem: Wolfshau) w Karpaczu (niem: Krummhübel) pochodzi z 1863 r. Mineralizację tę napotkano podczas eksploatacji pegmatytu na Kruczych Skałach (niem: Rabenstein) u ujścia Sowiej Doliny (Fiedler, 1863). Pozostałością po tych pracach są wyrobiska górnicze o łącznej długości około $15 \mathrm{~m}$ (Firszt, 2002).

Przedmiotem eksploatacji była tu żyła pegmatytu zalegająca w granitognejsach w niewielkiej odległości od ich kontaktu z intruzją granitu Karkonoszy. Występowały w niej pojedyncze, sześcienne kryształy uraninitu wielkości do $0,5 \mathrm{~cm}$ wrośnięte $\mathrm{w}$ skaleń potasowy. Były one częściowo rozłożone i otoczone obwódkami żółtego uranofanu i innych ochr uranowych (Fiedler, 1863; Lis \& Sylwestrzak, 1986).

Występująca na Kruczych Skałach mineralizacja uranowa nie była przedmiotem osobnego rozpoznania. Prowadzone w trakcie inwentaryzacji pomiary radiometryczne wykazały, że urobek skalny zgromadzony na przykopalnianej hałdzie, nie zawiera fragmentów rud uranu.

Żyła pegmatytu na Kruczych Skałach była udostępniona wgłębnie dwoma wyrobiskami górniczymi (ryc. 10).

Obiekt nr 12 to wyrobiska dawnej kopalni skalenia na Kruczych Skałach, położone nad potokiem Płomnica, u ujścia Sowiej Doliny, na wysokości około $636 \mathrm{~m}$ n.p.m. W miejscowej tradycji wiąże się je z poszukiwaniami kamieni szlachetnych (szafiry), które miały być prowadzone w tych okolicach w XV i XVI w. Charakterystyczne ślady świdrów na ociosach wskazują jednak, że wyrobiska te zostały wydrążone dopiero w XVIII lub na początku XIX wieku, prawdopodobnie w celu pozyskania surowca skaleniowego dla manufaktur por- 
celany w Berlinie. Wyrobisko górne o szerokości 3-5 m, wysokości 3,5-4 m. i $11 \mathrm{~m}$ długości, przebija się na powierzchnię po drugiej stronie skał. Wyrobisko dolne jest bardzo regularne. Ma ono wymiary około $4 \times 4 \times 4 \mathrm{~m}$ (Firszt, 2002).

Obecnie oba wyrobiska są drożne (ryc. 16). Poniżej, tuż przy potoku Płomnica znajduje się hałda. Wśród zalegającego na niej urobku występują głównie pegmatyty, którym w podrzędnych ilościach towarzyszą granitognejsy oraz skupienia i ziarna dość rzadkich minerałów takich jak korund, dumortieryt, ilmenit $\mathrm{i}$ in. Materiał ten wykazuje na ogół słabą aktywność promieniotwórczą mieszczącą się w przedziale $2-4 \mathrm{~Bq}$. Hałdę porasta drzewostan iglasty i roślinność trawiasta.

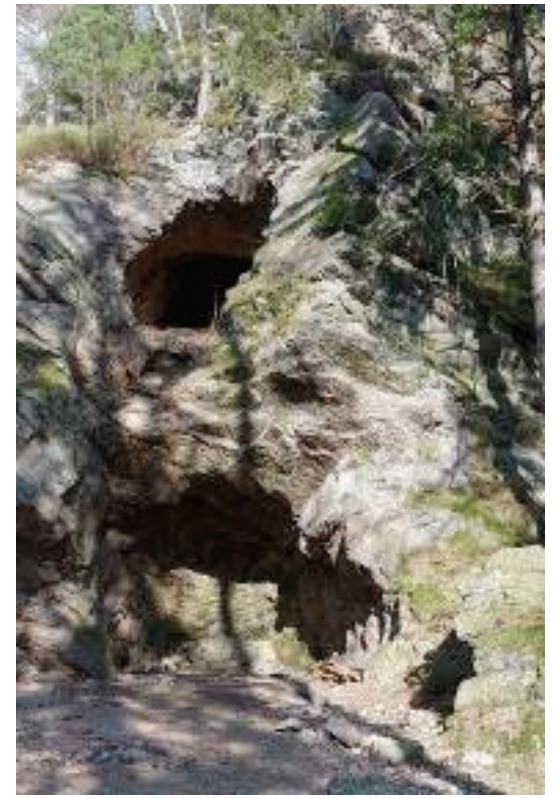

Ryc. 16. Wyrobiska po eksploatacji pegmatytu na Kruczych Skałach w Wilczej Porębie według stanu z 1.04.2017 r. (fot. D. Wójcik)

Fig. 16. Excavations after exploitation of pegmatite in Krucze Skały in Wilcza Poręba as of 01/04/2017 (photo D. Wójcik)

W 1951 r., w punkcie „Karpacz” położonym w odległości około 640 m na południe od Kruczych Skał wykryto anomalię radiometryczną (Adamski \& Kaczmarek, 1960), którą następnie rozpoznano pionowymi i poziomymi wyrobiskami górniczymi o łącznej długości 177,9 m.b. (Sztuk i in., 1994). Prace te nie doprowadziły jednak do znalezienia znaczących koncentracji rud uranu, w związku z czym w 1952 r. zostały przerwane (Adamski \& Kaczmarek, 1960).

Punkt „Karpacz” położony jest w dolinie potoku Płomnica w Wilczej Porębie (dzielnica Karpacza), u północno-zachodniego podnóża góry Skalny Stół (1281 m n.p.m.), w południowej części metamorficznej osłony intruzji granitu Karkonoszy. Na obszarze tym zalegają różne odmiany granitognejsów z wkładkami fyllitów. Mineralizacja uranowa związana tu była ze szczeliną tektoniczną o biegu NW-SE przecinającą kompleks granitognejsowy w odległości około 
$500 \mathrm{~m}$ od jego kontaktu z intruzją granitu Karkonoszy. Szczelina ta miała szerokość $0,1-0,4 \mathrm{~m}$ i była wypełniona brekcją granitognejsową oraz glinką tektoniczną. Rudy uranu zanikały jednak ze wzrostem głębokości (Adamski \& Kaczmarek, 1960).

$\mathrm{Z}$ powodu niewielkiej zawartości uranu w rudzie punkt ten uznano za nieperspektywiczny (Borucki, 1967). Na hałdy zrzucono tam łącznie około $600 \mathrm{~m}^{3}$ urobku skalnego (Sztuk i in., 1994). Prowadzone w trakcie inwentaryzacji pomiary radiometryczne wykazały, że nie zawiera on fragmentów rud uranu.

Strefa ta została rozpoznana na powierzchni licznymi szurfami, a także udostępniona wgłębnie szybem nr 1 (ryc. 10).

Obiekt nr 13, czyli szyb nr 1, położony jest w dolinie potoku Płonica, na północno-zachodnim zboczu góry Skalny Stół (1281 m n.p.m.), na wysokości około 677 m. n.p.m. Jego bicie rozpoczęto w 1951 r., w celu wgłębnego rozpoznania wykrytych na powierzchni anomalii radiometrycznych. Miał on głębokość $45 \mathrm{~m}$ i udostępniał dwa poziomy rozpoznawcze (-15 i $-45 \mathrm{~m}$ ), na których wykonano łącznie 132,9 m.b. wyrobisk górniczych. Efektem tych prac było wykrycie ubogiej mineralizacji uranowej, bez znaczenia przemysłowego, w związku z czym w 1952 r. zostały one wstrzymane (Adamski, 1960). W 1994 r. szyb ten był jeszcze na tyle głęboki, że stwarzał zagrożenie dla ludzi i zwierząt (Sztuk i in., 1994).

Obecnie szyb jest niedrożny, gdyż w miejscu jego zrębu powstało głębokie zapadlisko (ryc. 17a). Obok widoczne są fundamenty maszyny wyciągowej. Poniżej znajduje się hałda (ryc. 17b). Wśród zalegającego na niej urobku skalnego występują głównie granitognejsy którym w podrzędnych ilościach towarzyszą minerały żyłowe (kwarc). Materiał ten wykazuje na ogół słabą aktywność promieniotwórczą, mieszczącą się w przedziale 2-6 Bq. Hałdę porasta drzewostan iglasty i roślinność trawiasta.
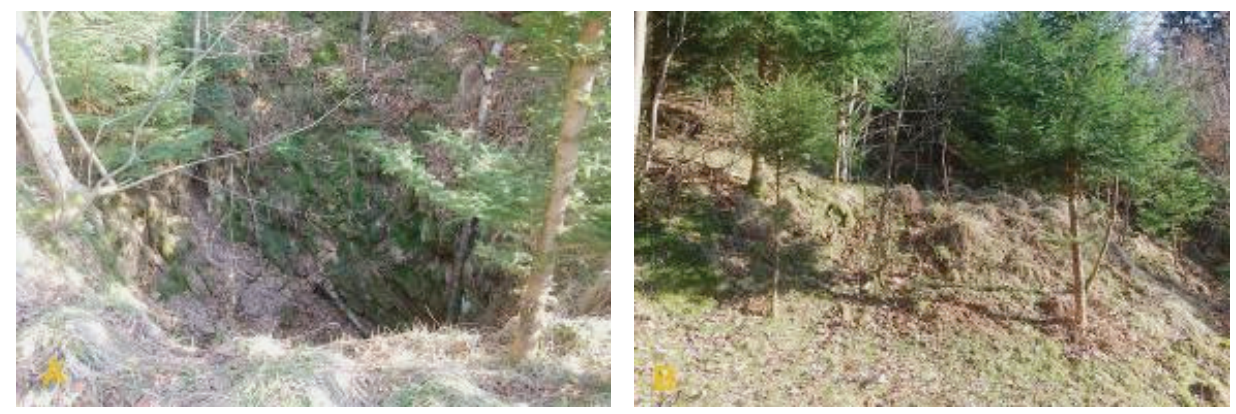

Ryc. 17. Punkt „Karpacz”: A - zapadlisko szybiku poszukiwawczego, B - hałda (stan z 7.04.2018 r., fot. D. Wójcik)

Fig. 17. "Karpacz" site: A - collapsed Shaft, B - tailing (photo 07/04/2018, D. Wójcik) 


\section{Rejon Szklarskiej Poręby}

W rejonie Szklarskiej Poręby intruzja granitu Karkonoszy kontaktuje od północy z serią skał metamorficznych (leukogranity, gnejsy i fyllity z wkładkami amfibolitów) budujących Góry Izerskie. W strefie przykontaktowej w skały te wnika duża ilość apofiz i dajek granitowych oraz różnego rodzaju skał żyłowych (mikrogranity, aplity, granity alkaliczne, pegmatyty i kwarc żyłowy), a tuż przy kontakcie z granitem zalega strefa hornfelsów powstałych w wyniku metamorfizmu termicznego fyllitów (ryc. 18). Związana $\mathrm{z}$ tą strefą mineralizacja ma nieco inny charakter niż w pozostałych częściach bloku karkonosko-izerskiego. Uran tworzy tu najczęściej domieszki w minerałach toru i pierwiastków ziem rzadkich, rzadko natomiast występuje w postaci własnych minerałów (Żaba, 1979; Lis \& Sylwestrzak, 1986). Mineralizację uranowotorową napotkano m. in. w dawnych kopalniach „Przy Starym Domu Celnym” na Skalnej Bramie i „Friedrich Wilhelm” w Szklarskiej Porębie Górnej oraz w sztolniach i szybikach na Zbójeckich Skałach w Szklarskiej Porębie Dolnej. Prawdopodobnie poszukiwano jej również w kopalni „Hilfe Gottes” na Czarnej Górze.

\section{Kopalnia skalenia na Skalnej Bramie}

Kopania skalenia określana mianem „Przy Starym Domu Celnym” (Lis \& Sylwestrzak, 1986) w Szklarskiej Porębie Górnej działała przypuszczalnie w pierwszej połowie XIX w. (Steć, 1963). Mineralizację uranowo-torową i pierwiastków ziem rzadkich wykryto tu jednak dopiero pod koniec lat 50. XX w. (Gajda, 1960a; 1960b).

Przedmiotem eksploatacji była tu żyła pegmatytu zalegająca w obrębie intruzji granitu Karkonoszy. Napotkano w niej wrośnięte w skaleń, pojedyncze, prawie sześcienne kryształy uraninitu $\mathrm{UO}_{2}$ otoczone spękaną, szarą lub zielonawą powłoką wtórnych ochr uranowych. Współwystępowały one z zawierającymi tor minerałami pierwiastkób)w ziem rzadkich (fergusonit, monacyt, cyrkon, ksenotym, gadolinit). Ponadto w ziemistym hematycie (śmietana hematytowa) wypełniającym wolne przestrzenie wśród minerałów tworzących druzy w pegmatycie dostrzeżono łuski wtórnych mik uranowych (Gajda, 1960a; 1960b; Lis, 1970).

Mineralizacja ta nie była przedmiotem osobnego rozpoznania górniczego. Prowadzone $\mathrm{w}$ trakcie inwentaryzacji pomiary radiometryczne wykazały, że materiał $\mathrm{z}$ hałd miejscami zawiera niewielkie skupienia minerałów promieniotwórczych. 


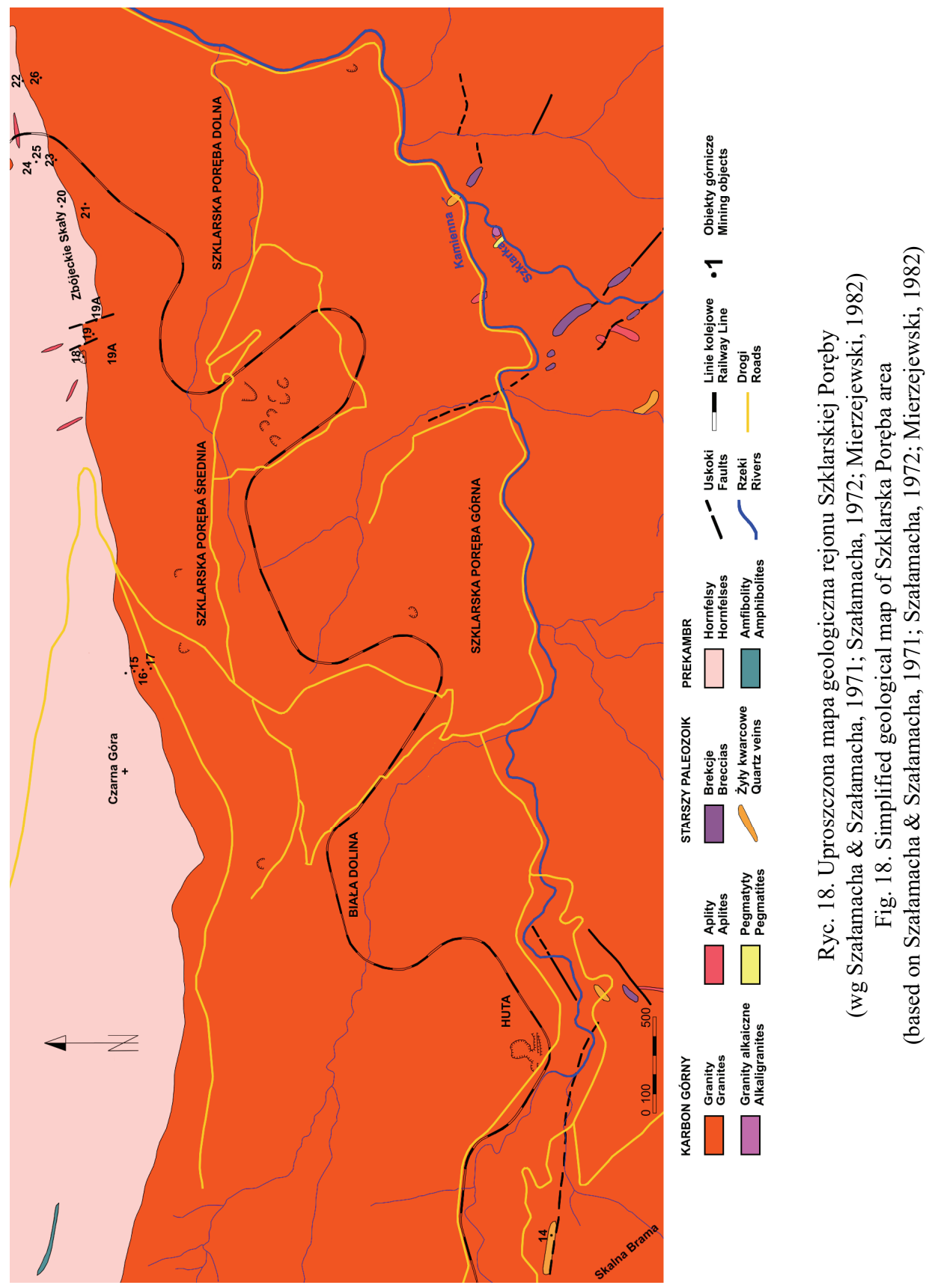


Obiekt nr 14 to wyrobiska dawnej kopalni skalenia „Przy Starym Domu Celnym", położone u podnóża północno-wschodniego zbocza wzgórza Skalna Brama (niem. Stockes-hübel), na wysokości około 797 m n.p.m., około 0,4 km na południowy wschód od Starego Domu Celnego (Gajda, 1960a; 1960b; Lis \& Sylwestrzak, 1986). Eksploatowana w niej żyła pegmatytu była udostępniona kilkunastometrowej długości sztolnią, w której założono trzy wyrobiska komorowe połączone ze sobą krótkimi chodnikami górniczymi.

Obecnie okno sztolni jest zapadnięte, ale poprzez zarwany strop jednej z komór poeksploatacyjnych (ryc. 19) można się przedostać do niektórych wyrobisk górniczych kopalni. Są one jednak częściowo zatopione. Poniżej znajduje się hałda. Wśród zalegającego na niej urobku skalnego występują głównie pegmatyty. Materiał ten wykazuje podwyższoną aktywność promieniotwórczą, sięgającą 2-12 $\mathrm{Bq}$, przy czym najwyższe promieniowanie (8-12 Bq) emitują podłużne, stalowoczarne wydzielenia hematytu. Hałdę porasta drzewostan iglasty i roślinność trawiasta.

W pobliżu znajdują się również inne zapadliska mogące świadczyć, że kopalnia miała znacznie większy zasięg. Nie udało się jednak tego potwierdzić w dostępnych źródłach.
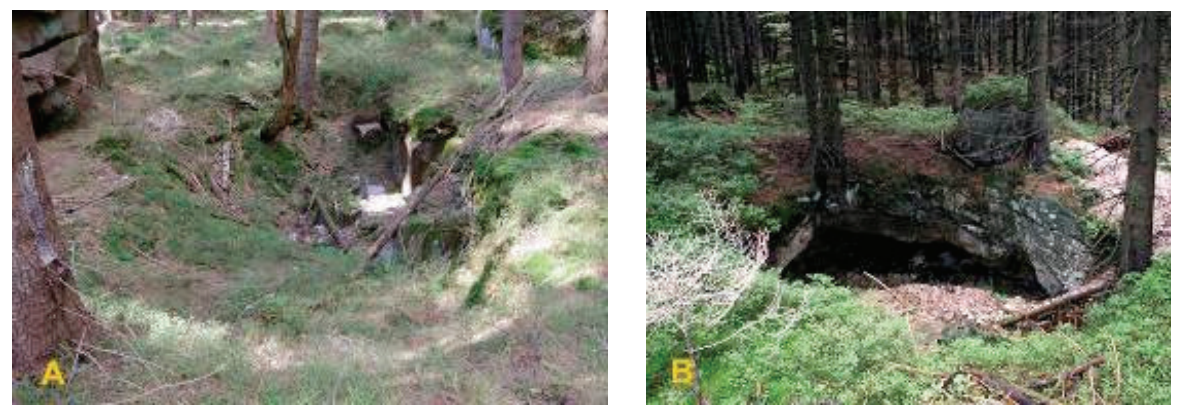

Ryc. 19. Zapadnięte komory eksploatacyjne kopalni „Skalna Brama”:

A - komora wschodnia według stanu z 8.04.2018 r (fot. D. Wójcik),

B - komora zachodnia według stanu z 30.09.2010 r. (fot. R. Borzęcki)

Fig. 19. Collapsed exploitation chambers of "Skalna Brama" mine:

A - eastern chamber as for 8/04/2018 (photo D. Wójcik),

B - western chamber as for 30/09/2010 (photo R. Borzęcki)

\section{Prace górnicze na zboczach Czarnej Góry}

Najstarsza wzmianka o wydobywaniu pirytów na zboczach Czarnej Góry (964,4 m n.p.m.) w Szklarskiej Porębie (niem: Schreiberchau) pochodzi z 1530 r. (Wiater, 2009). W 1545 r. planowano wznowienie tam robót górniczych, ale 
zamiar ten zrealizowano dopiero około $1550 \mathrm{r}$. Wydobywane rudy przerabiano w wybudowanej w Szklarskiej Porębie witriolejni (ługowni siarczanów żelaza i miedzi), która jest wzmiankowana już w 1553 r. (Dziekoński, 1972; Wiater, 2009). Później aż do końca XVI w. brak jakichkolwiek wzmianek o prowadzonych tu pracach górniczych (Dziekoński, 1972), co może świadczyć albo o tym, że były one prowadzone tylko okresowo, albo że wydobycie rudy miało w tym czasie niewielkie rozmiary. Działania wojny trzydziestoletniej (1618-1648) spowodowały upadek tutejszych robót górniczych. W 1735 r. podjęto próbę ich wznowienia, jednak zakończyła się ona niepowodzeniem. Pozytywne rezultaty przyniosły dopiero prace górnicze, rozpoczęte $1766 \mathrm{r}$. w dawnych wyrobiskach górniczych w Szklarskiej Porębie Górnej. Wkrótce potem uruchomiono tam kopalnię pirytów, która w 1768 r otrzymała nazwę „Friedrich Wilhelm” (Wiater, 2009).

W 1767 r. wznowiono także poszukiwania, w należących w tym czasie do gwarectwa „Friedrich Wilhelm” dawnych wyrobiskach górniczych, położonych na wschodnim zboczu Czarnej Góry. Wkrótce potem natrafiono w nich na żyłę kruszcową zawierającą do $20 \%$ kobaltu. W celu jej eksploatacji utworzono tam nowe gwarectwo o nazwie „Hülfe Gottes”. Znalezione rudy zalegały jednak w bardzo twardej skale, a ich zasoby okazały się niższe niż przypuszczano, w związku z czym w 1772 r. wszystkie prowadzone tu prace górnicze zostały wstrzymane. W $1775 \mathrm{r}$. podjęto próbę ich wznowieniaw w uruchomionej w dawnych wyrobiskach górniczych, nowej kopalni o nazwie „Julianen”, ale działała ona tylko rok. Cały uzyskany w tym czasie urobek wynosił zaledwie 250 kilogramów ręcznie wzbogaconego koncentratu rud kobaltu, który został przetopiony w hucie w Przecznicy (Dziekoński, 1972). Ogółem w latach 1767-1775 w kopalni „Hülfe Gottes” wykonano 168 m.b. poziomych i pionowych wyrobisk górniczych.

Pomyślnie rozwijały się natomiast prace górnicze prowadzone w tym czasie w kopalni „Friedrich Wilhelm”. Strefa rudonośna udostępniona tu była dwiema sztolniami o nazwach „Zur Ehre des Gottes” i „Zu des Menschen Besten”. W latach 1772-1787 wydobywano w nich rocznie do $400 \mathrm{t}$ pirytu oraz pewne ilości rud ołowiu i srebra. Surowiec przerabiano w odbudowanej i zmodernizowanej witriolejni w Szklarskiej Porębie, którą uruchomiono w 1773 r. Była to wówczas największa i najnowocześniejsza tego typu manufaktura w Prusach. Wytwarzano w niej olej podsiarczynowy (stężony kwas siarkowy), witriol zielony (siarczan żelaza), witriol niebieski (siarczan miedzi), witriol biały (siarczan cynku), czerwoną ochrę (tlenek żelaza) i siarkę (Wiater, 2009). Według opisu z 1800 r. witriolejnia ta przerabiała już tylko piryty sprowadzane z Miedzianki Śląskiej, co świadczy, że kopalnia „Friedrich Wilhelm” na Zbójeckich Skałach zakończyła swoją działalność przed końcem XVIII w (Krzyżanowski \& Wójcik, 2010). W 1811 r. w kopalni tej dostępnych było jeszcze około 214,5 m.b. poziomych i pionowych wyrobisk górniczych (Bocksch, 1811). 
W 1950 r. na odcinku około 2500 m pomiędzy „Zakrętem Śmierci” i Szklarską Porębą Dolną wykryto szereg miejsc występowania mineralizacji uranowotorowej i pierwiastków ziem rzadkich. W latach 1950-1951 obszar ten został pobieżnie rozpoznany wyrobiskami górniczymi o łącznej długości 571 m.b. (Adamski \& Kaczmarek, 1960).

Mineralizacja uranowo-torowa występuje wzdłuż północnego kontaktu intruzji granitu Karkonoszy ze skałami metamorficznej osłony tworzącymi zrąb Gór Izerskich. Była ona związana ze strefami biotytyzacji i sylifikacji granitów oraz kontaktujących z nimi hornfelsów (zmienione termicznie fyllity). Szczególnie wysokie koncentracje uranu i toru zaobserwowano w pobliżu przecinających te strefy szczelin tektonicznych (Adamski \& Kaczmarek, 1960).

W 1957 r. występujące w Szklarskiej Porębie przejawy mineralizacji uranowotorowej uznano za nieperspektywiczne i zaprzestano dalszych poszukiwań. Ta negatywna ocena wynikała głównie z braku umiejętności wzbogacania tutejszych rud oraz nieuwzględnienia wartości pierwiastków ziem rzadkich, które są ich głównym składnikiem. W podsumowaniu poszukiwań rud uranu w Sudetach z 1960 r. miejsce to uznano natomiast za perspektywiczne (Adamski \& Kaczmarek, 1960). Brak jednak informacji czy przeprowadzono tu później jakieś dodatkowe badania. Na hałdy zrzucono tam około $2800 \mathrm{~m}^{3}$ (około $8000 \mathrm{t}$ ) urobku skalnego (Sztuk i in., 1994; Sroga, 1997). Prowadzone w trakcie inwentaryzacji pomiary radiometryczne wykazały, że materiał ten miejscami zawiera fragmenty rud uranu.

Pomiędzy Czarną Górą i Szklarską Porębą Dolną zachowało się wiele śladów dawnej działalności górniczej. Pochodziły one z różnych okresów i dotyczyły różnych kopalin. Są to m. in. pozostałości kopalni rud kobaltu „Hülfe Gottes” (szyb „Tage” oraz sztolnie „Tage Rüsche” i „Der Tiefe”) na wschodnich zboczach Czarnej Góry, kopalni pirytu „Friedrich Wilhelm” (sztolnie, wyrobiska górnicze i liczne warpie) w Szklarskiej Porębie Górnej, a także wyrobiska poeksploatacyjne pegmatytów i wyrobiska poszukiwawcze Zakładów Przemysłowych R-1 (sztolnie nr 1 i 2, szybiki nr 1 i 2 oraz liczne szurfy) na Zbójeckich Skałach w Szklarskiej Porębie Dolnej (ryc. 18).

Obiekt nr 15 to szyb „Tage”, położony na południowo-wschodnim zboczu Czarnej Góry (964,4 m n.p.m.) na wysokości około 870 m n.p.m. (Żaba, 1979). Został prawdopodobnie zgłębiony około $1769 \mathrm{r}$. w ślad za wykrytą tu w $1767 \mathrm{r}$. żyłą kruszcową z domieszkami Co. Był on szybem wydobywczym kopalni „Hülfe Gottes”. (Dziekoński, 1972; Elster, 1771). Miał głębokość około 14 metrów i w podszybiu łączył się ze sztolnią „Tage Rüsche” (Elster, 1771; Grund..., 1775).

Obecnie szyb jest niedrożny, gdyż w miejscu jego zrębu powstało głębokie zapadlisko (ryc. 20a). Poniżej znajduje się hałda (Ryc. 20b). Wśród zalegającego na niej urobku skalnego występują głównie hornfelsy, którym w podrzędnych ilościach towarzyszą minerały żyłowe (kwarc). Materiał ten wykazuje słabą aktywność promieniotwórczą, mieszczącą się w przedziale 2-4 Bq. Hałdę porasta drzewostan iglasty i roślinność trawiasta. 

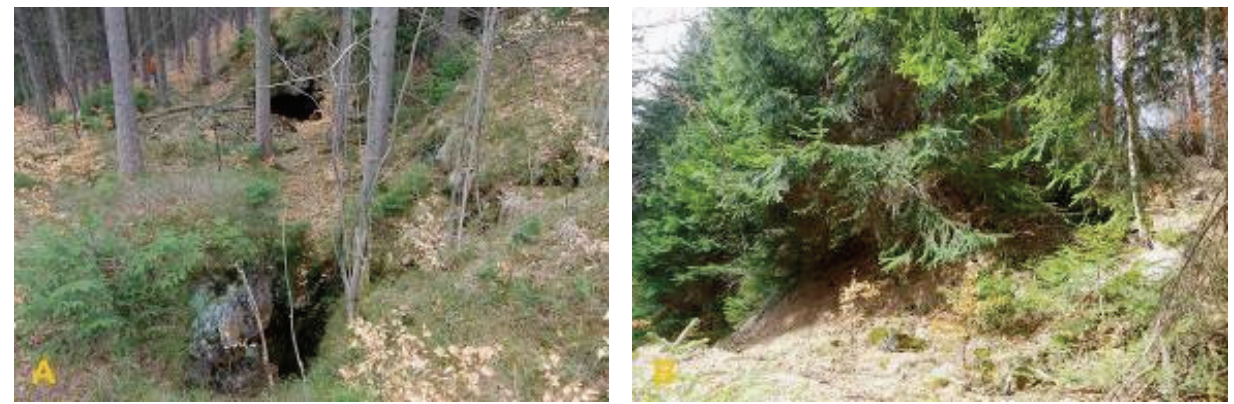

Ryc. 20. Szyb „Tage”: A - zapadlisko szybu; B - hałda (stan z 8.04.2018 r., fot. D. Wójcik)

Fig. 20. Shaft "Tage": A - collapsed shaft, B - tailing (photo 08/04/2018, D. Wójcik)

Przy szybie znajduje się odkrywka, w której wyeksploatowano wychodnię żyły kruszcowej. Po przeciwnej stronie prowadzono z niej krótkie wyrobisko, prowadzące do zgłębionego z powierzchni, płytkiego szybiku (obecnie prawie całkowicie zatopiony) prawdopodobnie o charakterze poszukiwawczym. Ogółem na poziomie tym wykonano $15 \mathrm{~m} . b$. wyrobisk górniczych.

Obiekt nr 16, czyli sztolnia „Tage Rösche”, położona jest na północnowschodnim zboczu Czarnej Góry (964,4 m n.p.m.), na wysokości około $860 \mathrm{~m}$ n.p.m. (Żaba, 1979). Została wydrążona przed 1771 r., w celu udostępnienia wykrytej tu w 1767 r. żyły kruszcowej z domieszkami Co (Dziekoński, 1972; Elster, 1771). Była ona sztolnią eksploatacyjną kopalni rud kobaltu „Hülfe Gottes”. Miała długość około $90 \mathrm{~m}$ i, poprzez szyb „Tage”, łączyła się z powierzchnią ziemi. Ponadto wydrążono w niej trzy krótkie wyrobiska poszukiwawcze oraz wybito dwa ślepe szybiki (Grund..., 1775). W 2002 r. dokonano pomiarów i sporządzono szczegółowy profil geologiczny dostępnego fragmentu sztolni (Zagożdżon \& Zagożdzon, 2002).
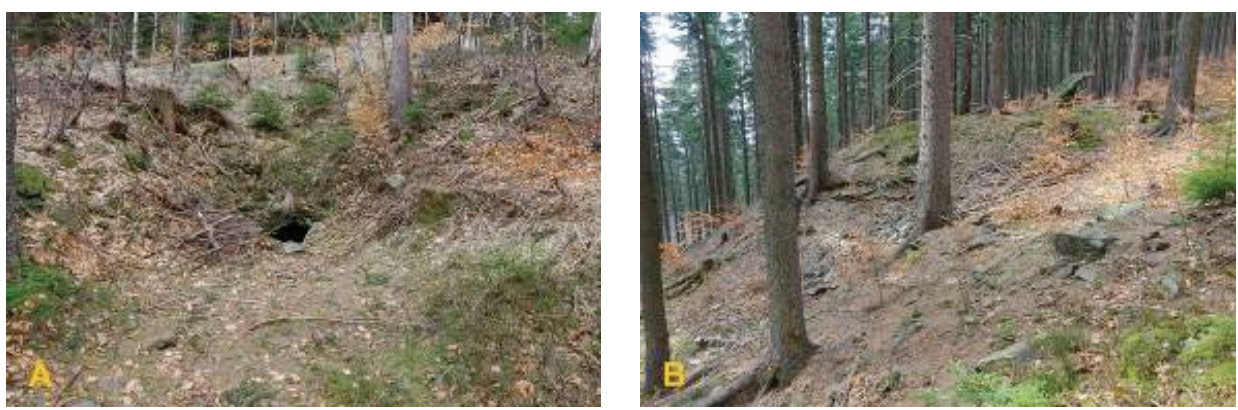

Ryc. 21. Sztolnia „Tage Rösche”: A - okno, B - hałda (stan z 8.04.2018 r., fot. D. Wójcik)

Fig. 21. "Tage Rösche” adit: A - window, B - tailing (photo 08/04/2018, D. Wójcik) 
Obecnie sztolnia jest drożna tylko na odcinku około $35 \mathrm{~m}$, a jej okno przegradza około 1,5 m wysokości obwał (ryc. 21a). Poniżej znajduje się niewielka hałda (ryc. 21b). Wśród zalegającego na niej urobku skalnego występują głównie hornfelsy, którym w podrzędnych ilościach towarzyszą granity, minerały kruszcowe, żyłowy kwarc i magnetyt $\mathrm{FeFe}_{2} \mathrm{O}_{4}$. Materiał ten wykazuje słabą aktywność promieniotwórczą, mieszczącą się w przedziale 2-4 Bq. Hałdę porasta drzewostan iglasty i roślinność trawiasta.

Obiekt nr 17 to sztolnia „Der Tiefe”, położona na północno-wschodnim zboczu Czarnej Góry (964,4 m n.p.m.) na wysokości około 835 m n.p.m. (Żaba, 1979). Została wydrążona przed 1771 r. Prawdopodobnie miała być dziedziczną sztolnią odwadniającą dla kopalni „Hülfe Gottes”. Ostatecznie jednak osiągnęła ona długość zaledwie około $32 \mathrm{~m}$. Wykonano w niej tylko jedno krótkie wyrobisko górnicze o długości około 2 m (Grund..., 1775). W 2002 r. dokonano pomiarów i sporządzono szczegółowy profil geologiczny sztolni (Zagożdżon \& Zagożdzon, 2002).

Obecnie sztolnia jest drożna, ale jej okno przegradza około 1,2 m wysokości obwał (ryc. 22a) za którym gromadzi się woda. Poniżej znajduje się hałda (ryc. 22b). Wśród zalegającego na niej urobku skalnego występują głównie granity, którym w podrzędnych ilościach towarzyszą hornfelsy, żyłowy kwarc i minerały kruszcowe. Materiał ten wykazuje słabą aktywność promieniotwórczą, mieszczącą się w przedziale 2-4 Bq. Hałdę porasta drzewostan iglasty i roślinność trawiasta.
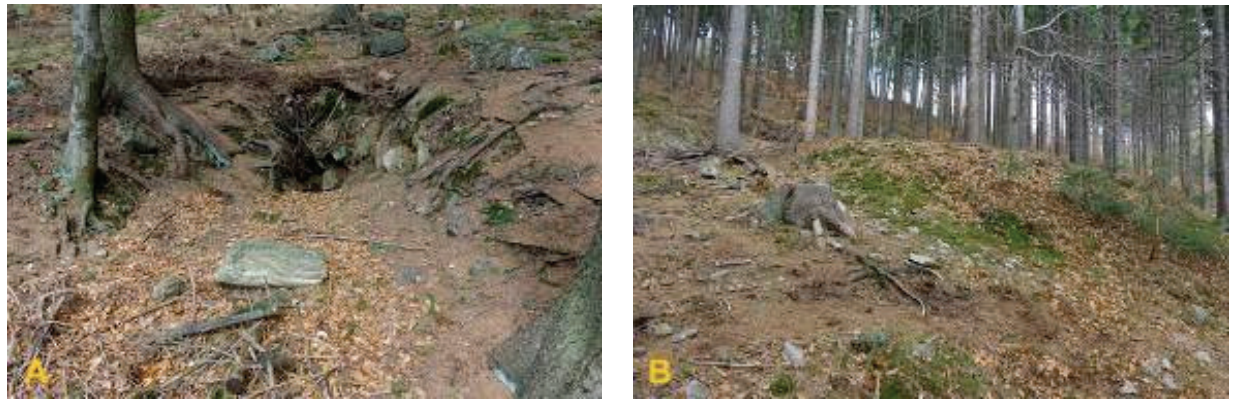

Ryc. 22. Sztolnia „Der Tiefe”: A - okno, B - hałda (stan z 8.04.2018 r., fot. D. Wójcik)

Fig. 22. Adit "Der Tiefe": A - window, B - tailing (photo 08/04/2018, D. Wójcik)

W lesie ponad szybem „Tage”, w jednej linii z opisanymi powyżej dawnymi wyrobiskami górniczymi kopalni „Hülfe Gottes”, znajduje się podłużny szurf, świadczący o tym, że w późniejszym okresie wykonano tu jakieś prace poszukiwawcze. Być może miały one związek z poszukiwaniami rud uranu, prowadzonymi w latach 1950-1951, na pobliskich „Zbójeckich Skałach” przez zakłady przemysłowe R-1 (Adamski \& Kaczmarek, 1961), lub rud cyny i kobaltu prowadzonymi w latach 1950-1957 w Górach Izerskich, przez Zakład Górniczy 
„Bolesław”, na zlecenie Sudeckich Zakładów Górniczych w Kowarach (Konstantynowicz, 1957).

Obiekt nr 18 - wyrobiska kopalni pirytu „Friedrich Wilhelm” - położony jest na południowo-wschodnim zboczu grzbietu górskiego pomiędzy „Zakrętem Śmierci” i „Zbójeckimi Skałami” w Szklarskiej Porębie Górnej, na wysokości około 710 m n.p.m. Eksploatowano tam pojedyncze ciało rudne, schodząc robotami górniczymi na głębokość około $14 \mathrm{~m}$ od powierzchni terenu. Strefa rudonośna udostępniona była na wychodni odkrywką o długości około $37 \mathrm{~m}$ oraz wgłębnie, sztolnią o długości około $41 \mathrm{~m}$, która prowadziła do dwupoziomowego ciągu wyrobisk górniczych i komór poeksploatacyjnych. Odkrywka była połączona z podziemną częścią kopalni ślepym szybikiem o głębokości około 9 m (Bocksch, 1811). Ogółem w kopalni „Friedrich Wilhelm” wykonano około 132 m.b. poziomych i pionowych wyrobisk górniczych. Po 1811 r., prawdopodobnie ze względów bezpieczeństwa, ale nie wykluczone również, że dla celów turystycznych, zestrzelono strop jednej z komór poeksploatacyjnych oddzielający ją od położonej nad nią odkrywki. Świadczą o tym widocznie w tym miejscu ślady po wierconych pionowo otworach strzałowych.

Obecnie okno sztolni jest zapadnięte (ryc. 23a), a jej dalszy odcinek całkowicie zatopiony, ale poprzez zarwany strop jednej z głównych komór poeksploatacyjnych (ryc. 23b) można się przedostać do innych wyrobisk górniczych kopalni. Niestety część z nich jest także całkowicie zatopiona. Poniżej znajduje się hałda (ryc. 24). Wśród zalegającego na niej urobku skalnego występują mocno przepojone limonitem hornfelsy. Materiał ten wykazuje słabą aktywność promieniotwórczą, mieszczącą się w przedziale 2-4 Bq. Hałdę porasta drzewostan liściasty i roślinność trawiasta.
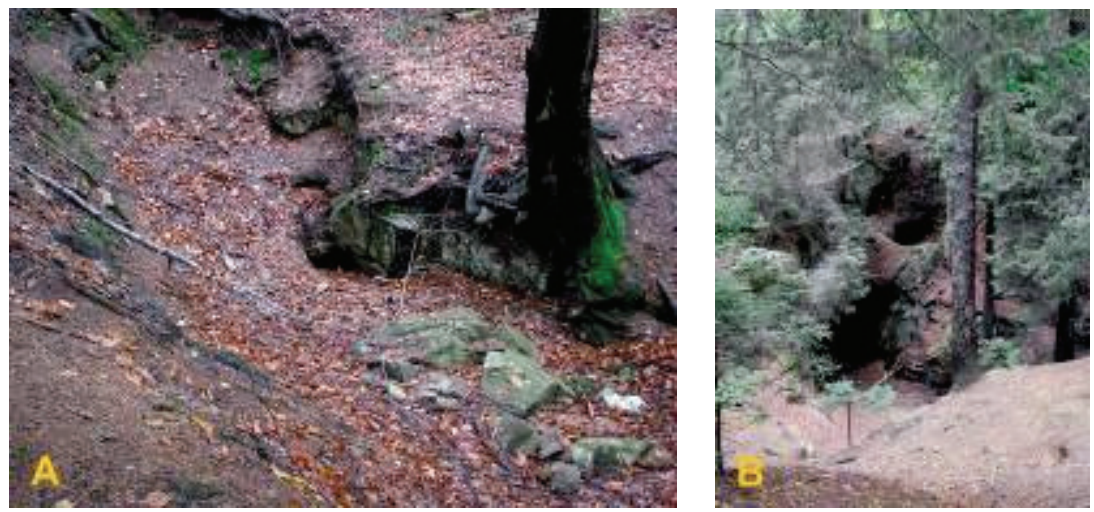

Ryc. 23. Kopalnia pirytu „Friedrich Wilhelm”: A - zapadnięte okno sztolni, B - wnętrze kopalni (stan z 30.09.2010 r., fot. R. Borzęcki)

Fig. 23. "Friedrich Wilhelm" Pyrite Mine: A - collapsed window of adit, B - central part of a mine (photo 30/09/2010, R. Borzęcki) 

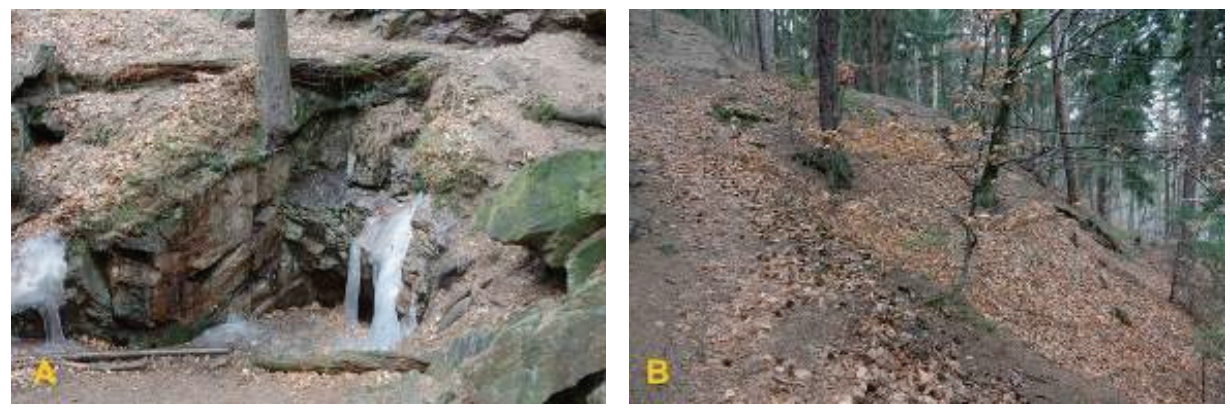

Ryc. 24. Kopalnia pirytu „Friedrich Wilhelm”: A - pozostałości podszybia ślepego szybiku, B - hałda (stan z 8.04.2018 r., fot. D. Wójcik)

Fig. 24. "Friedrich Wilhelm" Mine: A - remains of the shaft bottom of staple pit, B - tailing (photo 01/04/2018, D. Wójcik)

W pobliżu znajdowały się dwie inne sztolnie oraz liczne szybiki, które na mapie z $1811 \mathrm{r}$. zostały opisane jako stare, co może świadczyć ze pochodziły one jeszcze z XVI w. Niżej, mniej więcej w połowie wysokości wzniesienia położona była jeszcze jedna sztolnia o nazwie „Tiefer” (ryc. 18, punkt 18A), która miała być dziedziczną sztolnią odwadniającą kopalni „Friedrich Wilhelm", ale z powodu wyczerpania się zasobów złoża nie została ukończona (Bocksch, 1811). Wszystkie te obiekty są obecnie niedrożne.

Obiekt nr 19 to stara kopalnia kruszców (niem: „,Alte Kiessgrube”), położona na południowo-wschodnim zboczu grzbietu górskiego pomiędzy „Zakrętem Śmierci” i „Zbójeckimi Skałami”, na wysokości około 695 m n.p.m. Widnieje ona na mapie z 1811 r. jako część dawnej kopalni „Friedrich Wilhelm”, ale ma prawdopodobnie starsze, być może jeszcze szesnastowieczne, pochodzenie. Była sztolnią poszukiwawczą poprowadzoną w głąb zbocza z odkrywki, w której eksploatowano niewielkie ciało rudne (Bocksch, 1811). Miała długość około $18 \mathrm{~m}$. Ogółem wykonano w niej około 14,5 m.b. wyrobisk górniczych. W 1950 r. w trakcie poszukiwań w tym rejonie rud uranu, sztolnia ta została udrożniona i częściowo przebudowana (Adamski \& Kaczmarek 1960), a jej okno zabezpieczono betonowymi odrzwiami (ryc. 25a).

Obecnie sztolnia jest drożna, ale jej okno przegradza na wysokość około $1 \mathrm{~m}$ gruz skalny, zalegający na dnie odkrywki, utrudniający odpływ wody. Poniżej znajduje się niewielka hałda (ryc. 25b). Wśród zalegającego na niej urobku skalnego występują głównie hornfelsy którym w podrzędnych ilościach towarzyszą pegmatyty. Materiał ten wykazuje słabą aktywność promieniotwórczą, mieszczącą się w przedziale $4-8$ Bq. Hałdę porasta drzewostan iglasto-liściasty i roślinność trawiasta.

W odległości około $52 \mathrm{~m}$ na wschód od starej kopalni kruszcówc) widoczne jest podłużne zapadlisko, będące pozostałością po istniejącej tu sztolni (ryc. 18, 
punkt 19A), która na mapie z 1811 r. została opisana jako stara (Bocksch, 1811), co może świadczyć że pochodzi ona jeszcze z XVI w. Brak jest jednak o niej bliższych danych. Na znajdującej się poniżej hałdzie zalegają hornfelsy.
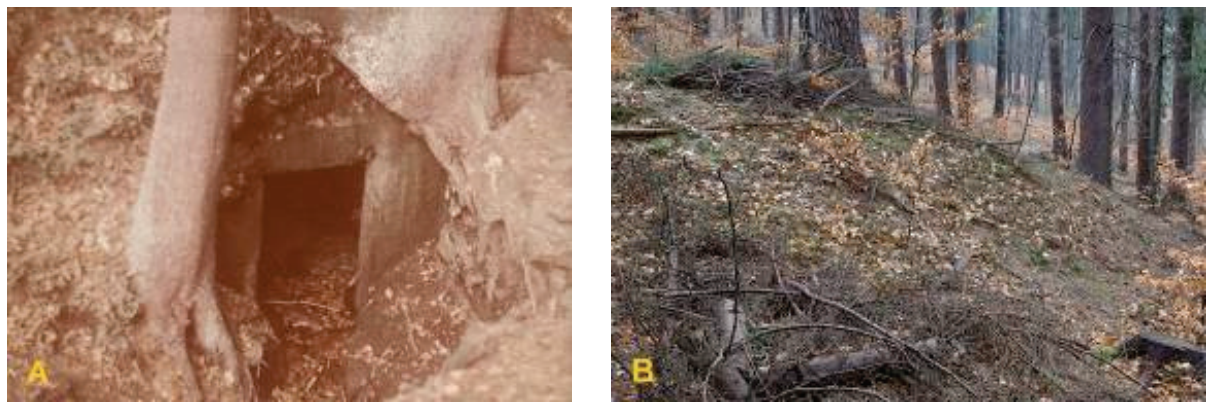

Ryc. 25. Sztolnia starej kopalni kruszców: A - okno według stanu z 10.10.1986 r.

(fot. R. Borzęcki), B - hałda według stanu z 8.04.2018 r. (fot. D. Wójcik)

Fig. 25. Adit of old ore mine: A - window as for 10/10/1986 (photo R. Borzęcki), B - tailing as for 08/04/2018 (photo D. Wójcik)

Obiekt nr 20 to bezimienna sztolnia, położona w pobliżu pomnika na „Zbójeckich Skałach" w Szklarskiej Porębie Dolnej, na wysokości około 651 m n.p.m. Miała ona długość około $38 \mathrm{~m}$. i biegła wzdłuż szczeliny tektonicznej, przecinającej strefę kontaktu hornfelsów i leżących za nimi granitów. Kontakt tych skał był dobrze widoczny na jej ociosach. Nie udało się ustalić kiedy i w jakim celu sztolnia ta została wykonana. Być może miała ona związek z prowadzonymi na tym terenie w drugiej połowie XIX w. poszukiwaniami rud żelaza (magnetytu).
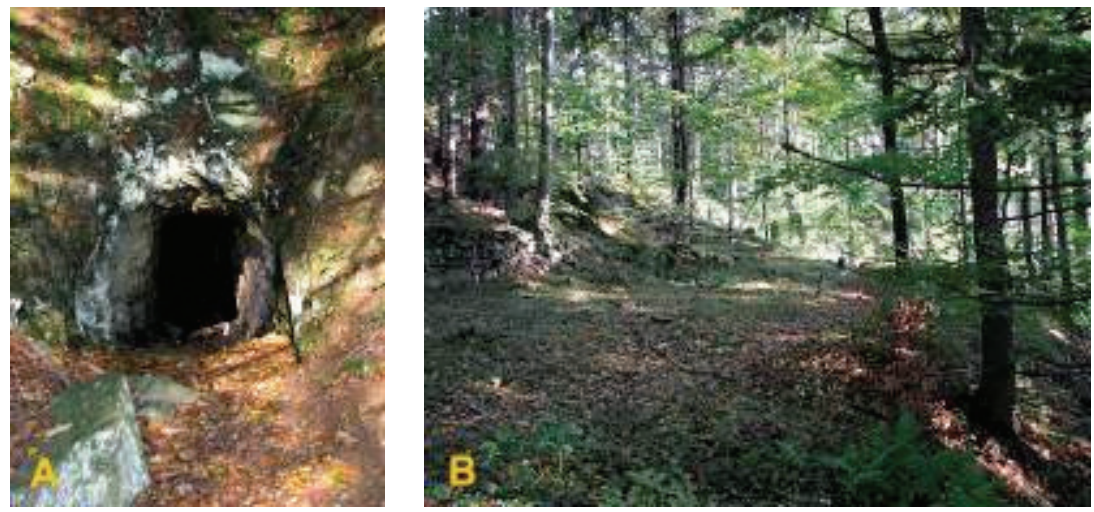

Ryc. 26. Bezimienna sztolnia (obiekt nr 20) w Szklarskiej Porębie Dolnej: A - okno, B - hałda (stan z 30.09.2010 r., fot. R. Borzęcki)

Fig. 26. Unnamed adit (object No. 20) in Szklarska Poręba Dolna: A - window, B - tailing (photo 30/09/2010, R. Borzęcki) 
Obecnie sztolnia jest drożna (ryc. 26a), ale na jej początkowym odcinku założono kratę uniemożliwiająca dalsze przejście. Poniżej znajduje się hałda (ryc. 26b). Wśród zalegającego na niej urobku skalnego występują głównie granity, którym w podrzędnych ilościach towarzyszą hornfelsy. Materiał ten wykazuje słabą aktywność promieniotwórczą, mieszczącą się w przedziale 2-4 Bq. Hałdę porasta drzewostan liściasty i roślinność trawiasta.

Obiekt nr 21 to bezimienna sztolnia położona poniżej „Zbójeckich Skał” w Szklarskiej Porębie Dolnej, na wysokości około 630 m n.p.m. Została wydrążona w 1883 r. na polu górniczym „Am Schwarzenberg Nr IV”, wyznaczonym w dniu 1.05.1868 r. dla ewentualnej kopalni pirytu i magnetytu. Była sztolnią poszukiwawczą, prowadzoną $\mathrm{w}$ celu rozpoznania mineralizacji magnetytowej, występującej na kontakcie granitu z hornfelsem. Miała ona długość około $120 \mathrm{~m}$ (Schneider, 1892). Na jej poziomie wykonano około 70 m.b. bocznych wyrobisk górniczych i jeden ślepy szybik. Prostokątny kształt początkowego fragmentu sztolni, charakterystyczny dla powojennego, górnictwa polskiego świadczy, że została ona ponownie udrożniona i częściowo przebudowana, podczas prowadzonych na tym terenie w latach pięćdziesiątych XX w. poszukiwań rud uranu.

Obecnie sztolnia jest drożna, ale jej okno przegradza około dwumetrowej wysokości obwał (ryc. 27a). Poniżej znajduje się hałda (ryc. 27b). Wśród zalegającego na niej urobku skalnego występują granity, którym, w podrzędnych ilościach, towarzyszą hornfelsy. Materiał ten wykazuje słabą aktywność promieniotwórczą, mieszczącą się w przedziale 2-4 Bq. Hałdę porasta drzewostan liściasty i roślinność trawiasta.
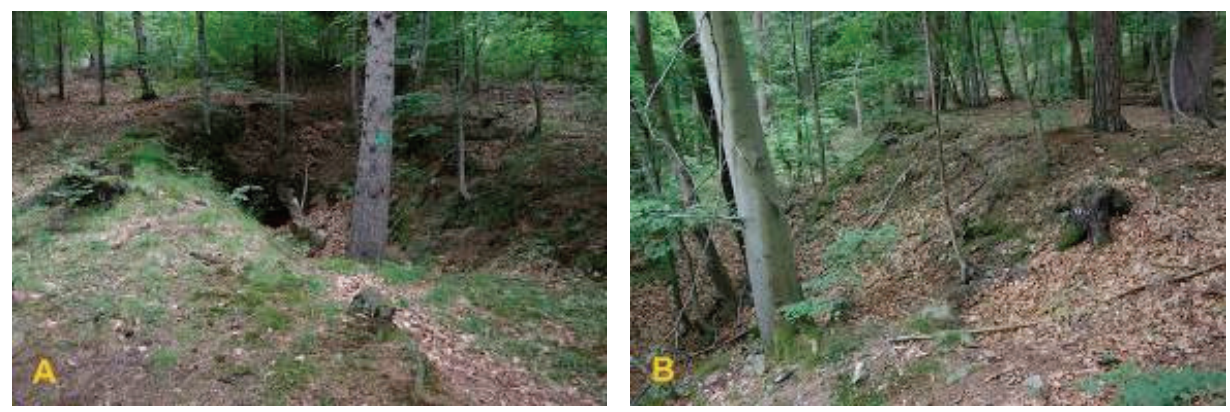

Ryc. 27. Bezimienna sztolnia (obiekt nr 21) w Szklarskiej Porębie Dolnej:

A - okno, B - hałda (stan z 30.06.2018 r., fot. D. Wójcik)

Fig. 27. Unnamed adit (object No. 21) in Szklarska Poręba Dolna:

A - window, B - tailing (photo 30/06/2018, D. Wójcik)

Obiekt nr 22 to bezimienna sztolnia położona na „Zbójeckich Skałach” w Szklarskiej Porębie Dolnej, na wysokości około 547 m n.p.m., o długości 
około 8 m (Żaba 1979). Nie udało się ustalić kiedy i w jakim celu została ona wykonana. Być może miała ona związek $\mathrm{z}$ prowadzonymi na tym terenie w drugiej połowie XIX w. poszukiwaniami rud żelaza (magnetyt).

Obecnie sztolnia jest drożna (ryc. 28a) ale jej okno przegradza około $2 \mathrm{~m}$ wysokości obwał. Poniżej znajduje się hałda (ryc. 28b). Wśród zalegającego na niej urobku skalnego występują hornfelsy. Materiał ten wykazuje słabą aktywność promieniotwórczą, mieszczącą się w przedziale $2-4 \mathrm{~Bq}$. Hałdę porasta drzewostan liściasty i roślinność trawiasta.
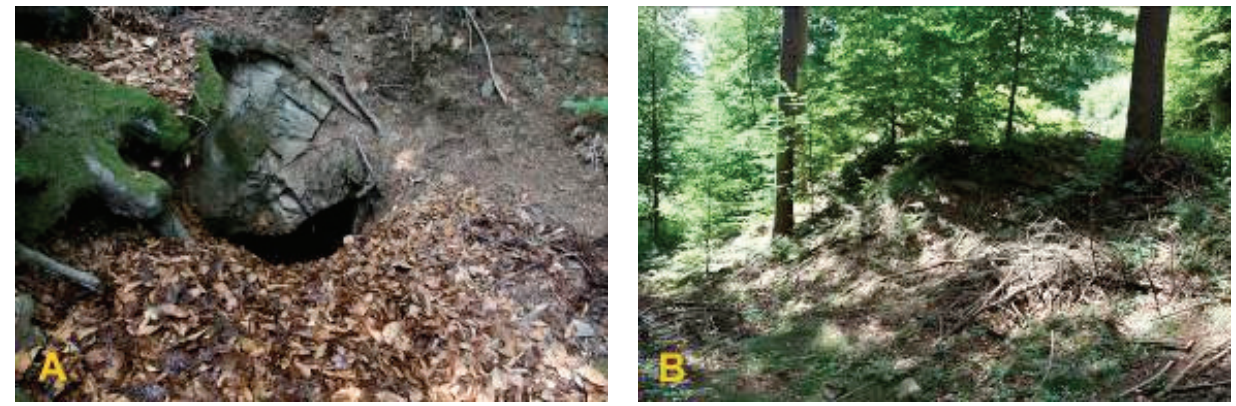

Ryc. 28. Bezimienna sztolnia (obiekt nr 22) w Szklarskiej Porębie Dolnej:

A - okno, B - hałda (stan z 30.06.2018 r., fot. M. Kalisz)

Fig. 28. Unnamed adit (object No. 22) in Szklarska Poręba Dolna:

A - window, B - tailing (photo 30/06/2018, M. Kalisz)

Obiekt nr 23 - sztolnia nr 1 - położona jest poniżej „Zbójeckich Skał” w Szklarskiej Porębie Dolnej, na wysokości około 610 m n.p.m., w pobliżu tunelu kolejowego linii Szklarska Poręba-Jelenia Góra. Została ona wydrążona w latach 1950-1951 r. w celu wgłębnego rozpoznania wykrytej na powierzchni strefy zmineralizowanej uranem, torem i pierwiastkami ziem rzadkich. Na jej poziomie wykonano łącznie około 80 m.b. wyrobisk górniczych. W 2002 r. wykonano pomiaryd) i sporządzono szczegółowy profil geologiczny sztolni. Mała ona wówczas długość około $187 \mathrm{~m}$, a poprowadzone z niej boczne wyrobiska - łącznie około 121 m.b. (Zagożdżon \& Zagożdzon, 2002). Świadczy to, że po 1951 r. prowadzono w niej jeszcze jakieś dodatkowe roboty górnicze.

Obecnie sztolnia jest drożna, ale jej okno przegradza około $2 \mathrm{~m}$ wysokości obwał (ryc. 29a). Około $5 \mathrm{~m}$ głębiej założona została krata która uniemożliwia dalsze przejście. Poniżej znajduje się hałda (ryc. 29b). Wśród zalegającego na niej urobku skalnego występują głownie granity, którym w podrzędnych ilościach towarzyszą hornfelsy. Materiał ten wykazuje podwyższoną aktywność promieniotwórczą, sięgającą miejscami $12 \mathrm{~Bq}$. Hałdę porasta drzewostan liściasty i roślinność trawiasta. 

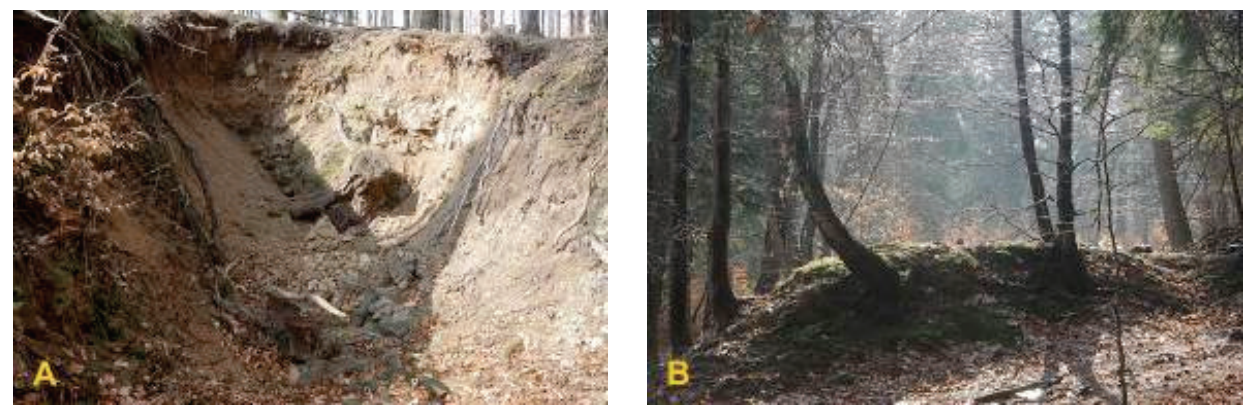

Ryc. 29. Sztolnia nr 1: A - zapadnięte okno, B - hałda (stan z 8.04.2018 r., fot. D. Wójcik)

Fig. 29. Adit No. 1: A - collapsed portal, B - tailing (photo 08/04/2018, D. Wójcik)

Obiekt nr 24, czyli szybik poszukiwawczy nr 1 położony jest poniżej „Zbójeckich Skał" w Szklarskiej Porębie Dolnej, na wysokości około 635 m n.p.m. Został wybity na początku lat pięćdziesiątych XX w. w celu wgłębnego rozpoznania wykrytej na powierzchni anomalii radiometrycznej.

Obecnie szybik jest niedrożny, gdyż w miejscu jego zrębu powstało zapadlisko (ryc. 30a). Poniżej znajduje się hałda (ryc. 30b). Wśród zalegającego na niej urobku skalnego występują głównie granity, którym w podrzędnych ilościach towarzyszą hornfelsy. Materiał ten wykazuje słabą aktywność promieniotwórczą, mieszczącą się w przedziale 2-4 Bq. Hałdę porasta drzewostan liściasty i roślinność trawiasta.
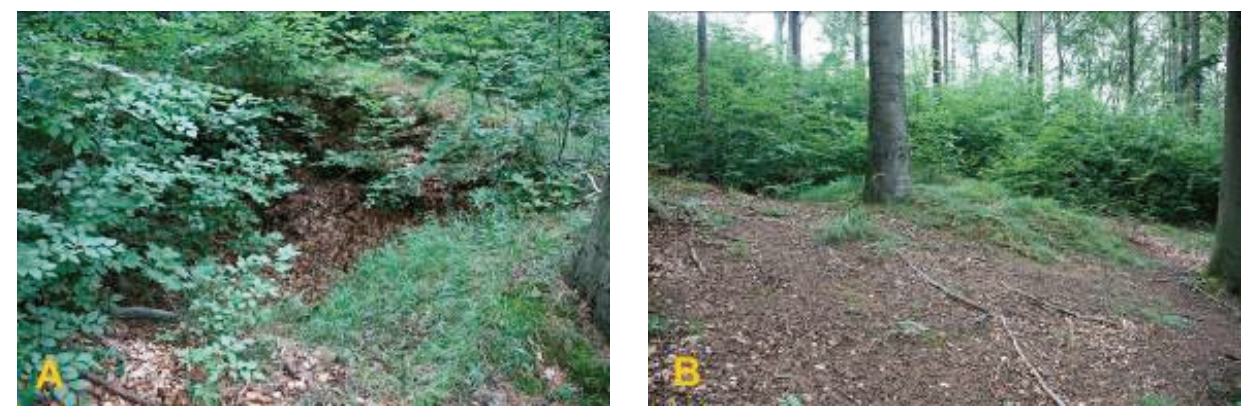

Ryc. 30. Szybik poszukiwawczy $\mathrm{nr} 1$ :

A - zapadlisko szybiku, B - hałda (stan z 30.06.2018 r., fot. M. Kalisz)

Fig. 30. Adit No. 1: A - collapsed shaft, B - tailing (photo 30/06/2018, M. Kalisz)

Obiekt nr 25 to szybik poszukiwawczy nr 2 położony poniżej „Zbójeckich Skał" w Szklarskiej Porębie Dolnej, na wysokości około 640 m n.p.m. Został wybity na początku lat pięćdziesiątych XX w. w celu wgłębnego rozpoznania wykrytej na powierzchni anomalii radiometrycznej. 
Obecnie szybik jest drożny na głębokości około $7 \mathrm{~m}$. Zachowały się w nim jeszcze pozostałości drewnianej obudowy (ryc. 31a). Poniżej znajduje się hałda (ryc. 31b). Wśród zalegającego na niej urobku skalnego występują głównie granity, którym w podrzędnych ilościach towarzyszą hornfelsy. Materiał ten wykazuje słabą aktywność promieniotwórczą, mieszczącą się w przedziale 2-4 Bq. Hałdę porasta drzewostan liściasty.
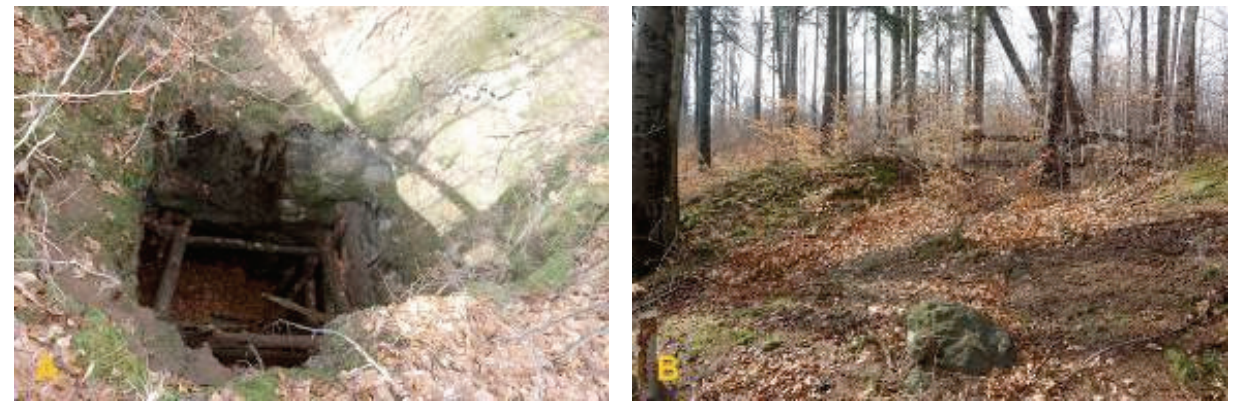

Ryc. 31. Szybik poszukiwawczy $\mathrm{nr}$ 2:

A - zapadlisko szybiku, B - hałda (stan z 8.04.2018 r., fot. D. Wójcik)

Fig. 31. Adit No. 2: A - collapsed schaft, B - tailing (photo 08/04/2018, D. Wójcik)
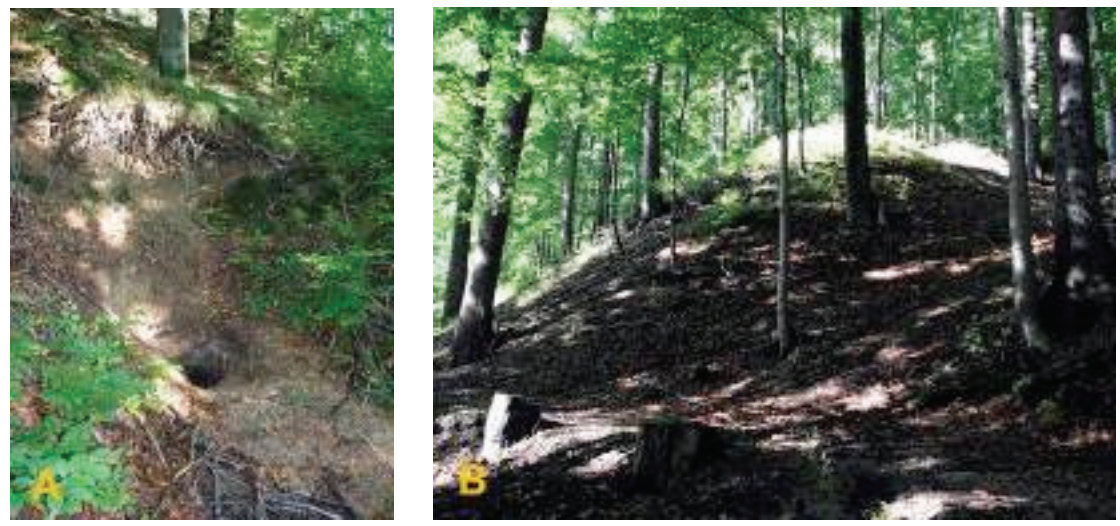

Ryc. 32. Sztolnia nr 2: A - okno, B - hałda (stan z 1.10.2010 r., fot. R. Borzęcki)

Fig. 32. Adit No. 2: a - window, b - tailing (photo 01/10/2010, R. Borzęcki)

Obiekt nr 26 to sztolnia nr 2 położona poniżej „Zbójeckich Skał” w Szklarskiej Porębie Dolnej, na wysokości około 520 m n.p.m. Została wydrążona w 1951 r. w celu wgłębnego rozpoznania wykrytej na powierzchni strefy zmineralizowanej uranem, torem i pierwiastkami ziem rzadkich. Na jej poziomie wykonano łącznie około 40 m.b. poziomych wyrobisk górniczych (Adamski \& Kaczmarek, 1960). W 1994 r. sztolnia była niedrożna (Sztuk, 1994). W 2002 r. była dostępna, co 
umożliwiło jej opomiarowanie i wykonanie profilowania geologicznego. Mała wówczas długość około $136 \mathrm{~m}$, a poprowadzone z niej wyrobiska górnicze około 99 m.b. (Zagożdżon \& Zagożdzon, 2002). Świadczy to o tym, że po 1951 r. przeprowadzono w niej jeszcze jakieś dodatkowe roboty górnicze.

Obecnie sztolnia jest drożna, ale jej okno przegradza około $1,5 \mathrm{~m}$ wysokości obwał (ryc. 32a). Poniżej znajduje się hałda (ryc. 32b). Wśród zalegającego na niej urobku skalnego występują granity. Materiał ten wykazuje na ogół słabą aktywność promieniotwórczą, mieszczącą się w przedziale 4-8 Bq. Hałdę porasta drzewostan liściasty.

\section{Podsumowanie}

Prace górnicze prowadzone w rejonie Jeleniej Góry i Szklarskiej Poręby mają wielowiekowe tradycje. Na obszarze tym, w różnych okresach czasu, wydobywano m. in. rudy kobaltu (kopalnia „Hülfe Gottes”), piryty (kopalnia „Friedrich Wilhelm”) i pegmatyty (kopalnie na Kruczych Skałach i „Przy Starym Domu Celnym” oraz wyrobiska górnicze na Zbójeckich Skałach). Pozostałością po nich są zachowane do dnia dzisiejszego liczne hałdy oraz zapadliska szybików i sztolni, a miejscami również fragmenty podziemnych wyrobisk górniczych. Prace te nigdy jednak nie rozwinęły się na większa skalę. Na podstawie zachowanych map górniczych i danych archiwalnych obliczono, że $\mathrm{w}$ opisywanych kopalniach $\mathrm{w}$ drugiej połowie XVIII w. wykonano w sumie tylko około 397 m.b. pionowych i poziomych wyrobisk górniczych. Łączna długość chodników i szybików wydrążonych tu we wcześniejszym okresie czasu nie jest znana, ale zapewne była ona również niewielka. W większości przypadków nieznana jest także całkowita ilość wydobytych w tych kopalniach surowców.

Niewątpliwie największe rozmiary miały prowadzone w opisywanych rejonach w latach pięćdziesiątych XX w. prace górnicze związane z poszukiwaniami rud uranu. W ich efekcie wykonano tu w sumie 5487,9 m.b. podziemnych wyrobisk górniczych. Pozostałością po nich są również liczne hałdy, na których zgromadzono około $27750 \mathrm{~m}^{3}$ urobku skalnego. Prace te jednak, również nie przyniosły większych rezultatów, gdyż wydobyte rudy zawierały w sumie tylko $126,025 \mathrm{~kg}$ uranu.

Wieloletnie obserwacje wykazały, że występujące w opisywanych rejonach pozostałości górnictwa ulegają stopniowo rekultywacji. Część dostępnych jeszcze wejść do podziemnych wyrobisk górniczych została skutecznie zlikwidowana lub zabezpieczona kratami. W ostatnim czasie obserwuje się jednak nasilenie prób ponownego otwarcia niektórych sztolni. Działania te prowadzone są najczęściej w spontaniczny i niekontrolowany sposób, stwarzając zagrożenie 
dla ludzi i środowiska a także bardzo negatywnie wpływając na stan samych wyrobisk.

Zalegające na tym obszarze dość liczne hałdy pokopalniane w większości przypadków nie stanowią już zagrożenia. Po zakończeniu eksploatacji zostały one zrekultywowane, zalesione i obecnie ładnie wkomponowują się w krajobraz. Jedyne niebezpieczeństwo dla ludzi i środowiska stwarza tylko hałda niskoprocentowej rudy zalegająca przy szybiku nr $3 \mathrm{w}$ Trzcińsku oraz dość rozległa hałda popirytowa przy kopalni „Friedrich Wilhelm” w Szklarskiej Porębie.

Biorąc pod uwagę wielowiekowe tradycje górnicze Karpacza i Szklarskiej Poręby wydaje się uzasadnione podjęcie prac mających na celu zabezpieczenie unikalnych fragmentów dawnych wyrobisk górniczych. Wyrobiska i hałdy stanowiące zagrożenie dla ludzi i środowiska, po uprzednim gruntownym przebadaniu, powinny zostać całkowicie zlikwidowane.

\section{Literatura}

ADAMSKI W., KACZMAREK J., 1960. Ocena uranonośności Sudetów. Zakł. Przemysł. R-1, 2, 1. Kowary.

BOCKSCH M., 1811. Situations Plan Der Gegend von der Friedrich Wilhelm Grube bis zur alten Julianen Grube gegen Abend nebst denen bei beiden Gruben besindlichen alten Stollen, Schächten u: Schürfen zur Untersuchung des Vitriolkieslagers am südlichen Gehänge des schwarzen Berges bei Schreiberau. Arch. Państw. w Katowicach, nr inw. 12396 OBB II 1164.

BORZĘCKI R., 2004. Górnictwo uranu w Polce. Otoczak, 31: 28-43.

BORZĘCKI R., MAREK A., 2016. Pozostałości górnictwa rud uranu w Masywie Śnieżnika. Hered. Min., 3: 109-133.

BORZĘCKI R., WÓJCIK D., 2017. Pozostałości górnictwa rud uranu i żelaza w rejonie Kowar, częśś I. Hered. Min., 4: 81-108.

BORKOWSKA M., 1966. Petrografia granitu Karkonoszy. Geol. Sud., 2: 7-30.

BORUCKI J., GŁOWACKI Z., MASŁOWSKI W., SAŁDAN M., UBERNA J., ZAJĄCZKOWSKI W., 1967. Ocena perspektyw poszukiwawczych złoż rud uranu w Polsce. Prace IG. Wyd. Geol. Warszawa.

DZIEKOŃSKI T., 1972. Wydobywanie i metalurgia kruszców na Dolnym Śląsku od XIII do połowy XX wieku. Wyd. PAN. Wrocław.

ELSTER, 1771. Grund und Profil Riss von der zu Schreibersau am Schwartzenberg belegenen Kobald Grube, die Hülfe = Gottes genannt. Kopia z 1776 r. wykonana przez E.L.G. Abta. Arch. Państw. w Katowicach, nr inw. 12396 OBB II 116611771.

FIEDLER H., 1863. Die Mineralien Schlesiens mit Berücksichtigung der angrenzenden Länder. Verl. Von F.E.C. Leuckart. Breslau.

FIRSZT S., 2002. Badania archeologiczne nad dawnym górnictwem i hutnictwem $w$ Kotlinie Jeleniogórskiej, Karkonoszach i Górach Izerskich. [W:] Grodzicki A., Lorenc M.W. (red.). Uczniowie Agricoli, materiały z konferencji górniczej w Kowarach z 1999 roku. Wyd. Muz. Kark. w Jel. Górze. Jelenia Góra: 84-104.

GAJDA E., 1960a. Minerały żyt pegmatytowych okolic Szklarskiej Poręby (Karkonosze). Kwart. Geol., 3: 545-562. 
GAJDA E., 1960b. Żyty pegmatytowe okolic Szklarskiej Poręby (Karkonosze). Kwart. Geol., 3: $565-583$.

Grund-und Profil-Riss von dem zu Schreiberau belegenen Kobald-Bergwerk, die Juliane genant. 1775. Archiwum Państwowe w Katowicach. Zbiór OBB.

https://polska-org.pl/759730,foto.html?idEntity=535349 - witryna internetowa polska-org.pl Stowarzyszenia Wratislaviae Amici (dostęp: grudzień 2018).

KONSTANTYNOWICZ E., 1957. Problem cynowości lupków kwarcowo-serycytowych z chlorytem w rejonie Gierczyn-Przecznica. Rudy i Met. Nieżel., 3: 69-76.

KOZDRÓJ W., IHNATOWICZ A., CWOJDZIŃSKI S., PACUŁA J., 2009. Szczegółowa mapa geologiczna Polski 1:50000, Ark. Kowary (M33-44-D). Wyd. PIG. Warszawa.

KRZYŻANOWSKI K., WÓJCIK D., 2010. O kwasie siarkowym, złocie glupców i górnictwie w Szklarskiej Porębie. Sudety, 9: 6-9.

KRZYŻANOWSKI K., WÓJCIK D., 2012. Kopalnia kobaltu w Szklarskiej Porębie. Dzieje górnictwa - element europejskiego dziedzictwa kultury, 4: 221-234.

LEISNER E., 1865. Einige neue Mineral-Vorkommnisse aus Schlesien. Neues Jahrb. für Mineralog., Geol. und Paläont.: 457-458.

LIS J., 1970. Geochemia niektórych pierwiastków w granitoidowym masywie Karkonoszy. Biul. IG, 224: 6-102.

LIS J., STĘPIŃSKI M., SYLWESTRZAK H., 1965. Branneryt i mineraty wspótwystepujace $w$ żyle kwarcowej z Wołowej Góry koło Kowar. Biul. PIG, 133: 207-223.

LIS J., SYLWESTRZAK H., 1986. Mineraty Dolnego Ślaska. Wyd. Geol. Warszawa.

MIERZEJEWSKI M.P., 1982. Szczegółowa mapa geologiczna Sudetów, Ark. Szklarska Poręba. 1:25000. Wyd. Geol. Warszawa.

MOCHNACKA K., 1967. Geologia polimetalicznego złoża w Kowarach (Dolny Śląsk). Pr. Geol. Kom. Nauk PAN Oddz. w Krakowie, 40.

Rozporządzenie Rady Ministrów z dnia 6 sierpnia 2002 roku w sprawie przypadków, w których działalność zwiąana z na promieniowanie jonizujące nie podlega obowiazkowi uzyskania zezwolenia albo zgloszenia, oraz przypadków, w których może być wykonywana na podstawie zgłoszenia. Warszawa. Dz. Ust. Nr 137, Poz. 1153.

Rozporzadzenie Rady Ministrów z dnia 3 grudnia 2002 roku w sprawie odpadów promieniotwórczych $i$ wypalonego paliwa jądrowego. Warszawa. Dz. Ust. Nr 230, poz. 1925.

Rozporządzenie Rady Ministrów z dnia 18 stycznia 2005 roku w sprawie dawek granicznych promieniowania jonizujacego. Warszawa. Dz. Ust. Nr 20, Poz. 168.

SCHNEIDER G., 1892. Der Bergbau am Schwarzen Berge bei Schreiberchau. Der Wanderer im Riesengebirge, 12, 9: 114-120.

SROGA C., 1997. Mineralne surowce odpadowe Sudetów i Przedgórza Sudeckiego 1:200 000. Wyd. Geol. Warszawa.

SZAŁAMACHA J., 1960. Szczególowa mapa geologiczna Sudetów, Ark. Kowary. 1:25 000. Wyd. Geol. Warszawa.

SZAŁAMACHA J., 1972. Szczególowa mapa geologiczna Sudetów, Ark. Piechowice. 1:25 000. Wyd. Geol. Warszawa.

SZAŁAMACHA J., SZAŁAMACHA M., 1971. Szczegótowa mapa geologiczna Sudetów, Ark. Rozdroże Izerskie. 1:25000. Wyd. Geol. Warszawa.

SZAŁAMACHA M., TUCHOLSKA K., 1960. Szczegółowa mapa geologiczna Sudetów, Ark. Jelenia Góra-Wschód. 1:25 000. Wyd. Geol. Warszawa.

SZTUK H., ADAMSKI W., GAWOR F., 1994. Inwentaryzacja uszkodzeń środowiska na skutek prowadzenia poszukiwań $i$ eksploatacji złóż uranowych. Rap. Inst. Górn. Polit. Wr. I-11/ S-5/94. Wrocław. 
WIATER P., 2009. Witriolejnia i kopalnie pirytu w Szklarskiej Porębie Dolnej. Rocz. Jeleniog., 41: 43-47.

ZAGOŻDŻON K., ZAGOŻDŻON P., 2002. Charakterystyka niektórych sztolni rejonu Szklarskiej Poręby. Pr. Nauk. Inst. Górn. Polit. Wr., 102, Studia i Materiały, 29: 229-235.

ZAGOŻDŻON P., ZAGOŻDŻON K., 2007. Wstępna charakterystyka geologiczna sztolni po poszukiwaniach uranu w Jagniątkowie. Pr. Nauk. Inst. Górn. Polit. Wr., 118, Studia i Materiały, 33: 129-135.

ŻABA J., 1979. Pólnocny kontakt granitu Karkonoszy z rejonie Zakrętu Śmierci i Mniszego Lasu (Sudety Zachodnie). Geol. Sud., 14, 2: 47-71.

\title{
REMNANTS OF URANIUM, THORIUM AND ORES IN THE REGION OF JELENIA GÓRA AND SZKLARSKA PORĘBA
}

\author{
mining of uranium, history of mining, \\ Maciejowa, Trzcińsko, Jagniątków, Szklarska Poręba
}

The article presents a brief history and the state of conservation of the mining works in the Jelenia Góra region. It presents the results of the inventory work carried out in the "Majewo" mine in Maciejowa, the feldspar mine "At the Old Customs House" at the foot of the slope of the Skalna Brama, the ore mines "Hilfe Gottes" and "Friedrich Wilhelm" in Szklarska Poręba Górna, as well as in several places in the vicinity of Trzcińsko, Jagniątków, Wołcza Góra, Budniki, Karpacz and Szklarska Poręba. The inventory covered 25 mining objects (shafts, tunnels, open pits, heaps, etc.) that have been tested in terms of mineralogy, petrography and radiometry and documented photographically. Historical research was also carried out in archives and libraries. The summary includes the estimated length of all mining workings and the volume of uranium ore extraction (converted into pure metal) and other raw materials in the mines of Jelenia Góra and Szklarska Poręba.

During the inventory work, destructive changes in the described mining facilities were observed over time. The results of the reclamation work carried out here are also presented, aiming at minimising the harmful effects of different types of mining remnants on humans and the environment.

The summary includes the estimated length of all mining workings and the volume of uranium ore extraction and other raw materials in the mines of Jelenia Góra and Szklarska Poręba. 